MICHAE TYMOWSKI

Instytut Historyczny

Uniwersytetu Warszawskiego

\title{
KULTUROWO-PSYCHOLOGICZNE ASPEKTY OBECNOŚCI NIEWOLNIKÓW AFRYKAŃSKICH W PORTUGALII W XV I NA POCZĄTKU XVI W.
}

Zjawisko niewolnictwa w Portugalii w późnym średniowieczu i w czasach nowożytnych było przedmiotem badań historiografii portugalskiej od ostatnich dziesięcioleci XIX w. Jednakże przełomowe znaczenie miało dzieło Charlesa Verlindena, którego tom pierwszy, wydany w 1955 r., dotyczył średniowiecznego niewolnictwa na Półwyspie Iberyjskim i we Francji. Rozdział szósty tej pracy poświęcony został niewolnictwu w Portugalii w epoce wielkich odkryć2.

Ch. Verlinden przedstawił w nim źródła niewolnictwa, ocenił motywy wypraw portugalskich, takie jak dążenie do chrystianizacji ludów Afryki i chęć osiągnięcia zysków, oraz wpływ tych motywów na zjawisko niewolnictwa. Przeanalizował opłacalność handlu niewolnikami. Opisał dziedziny, w których niewolnicy afrykańscy zatrudniani byli w Portugalii (przeważnie pracowali jako służba domowa, ponadto jako rzemieślnicy, a sporadycznie w rolnictwie). Verlinden pisał zarówno o niewolnikach czarnych, jak i białych Maurach, poruszył także sprawę niewolników pochodzenia żydowskiego.

W badaniach podejmowanych po opublikowaniu dzieła Verlindena dominowały dwa kierunki zainteresowań, wynikające zresztą z tej pod-

\footnotetext{
* Praca finansowana ze środków na naukę w latach 2009-2012 jako projekt badawczy.

${ }^{1}$ A.P. de Carvalho, Das Origens da Escravidão Moderna em Portugal, Lisboa 1877; P. A. de Azevedo, Os Escravos, „Archivo Historico Portuguez” 1, 1903, 9, s. 289-307; M. Heleno, Os Escravos em Portugal, Lisboa 1933; A. Brásio, Os Pretos em Portugal, Lisboa 1944; E. C. Lopes, A Escravatura: Subsidios para a sua Historia, Lisboa 1944.

${ }^{2}$ Ch. Verlinden, L'Esclavage dans l'Europe Médiévale, t. 1: Pénisule Ibérique - France, Brugge 1955, s. 615-632.
} 
stawowej pracy. Zajmowano się gospodarczym lub społecznym znaczeniem niewolnictwa.

Vitorino Magalhães Godinho, Vicenta Cortez Alonso i Virginia Rau analizowali właśnie ekonomiczną stronę niewolnictwa okresu wczesnych wypraw portugalskich do Afryki ${ }^{3}$. Również Marian Małowist i John L. Vogt badali znaczenie handlu niewolniczego dla zagospodarowania Wyspy Świętego Tomasza i zorganizowania tam plantacji trzciny cukrowej ${ }^{4}$.

Problematykę społeczną podejmował Peter E. L. Russell ${ }^{5}$. Syntezą społecznej historii czarnego niewolnictwa w Portugalii od XV do połowy XVI w. jest dzieło Alastaira C. de C. M. Saundersa ${ }^{6}$.

Niewolnictwo i obecność w Portugalii XV i XVI w. niewolników afrykańskich - czarnych i białych (Berberów i Arabów) - miały istotny wpływ na historię tego państwa i na wiele dziedzin życia społecznego oraz na obyczaje i kulturę portugalską. Badania z zakresu kultury i literatury dotyczyły przede wszystkim obrazu ludzi czarnych w sztuce portugalskiej późnego średniowiecza i czasów nowożytnych.Jean Devisse i Michel Mollat rozszerzyli zakres tych badań na całą sztukę europejską ${ }^{7}$. Inny, intensywnie eksploatowany kierunek badań związanych z obecnością czarnych niewolników w Portugalii XV i XVI w. wytyczyli językoznawcy i literaturoznawcy. Badania ich dotyczą odrębnej, uproszczonej formy języka portugalskiego, którą posługiwali się niewolnicy. Była to tak zwana fala de Guiné lub fala dos pretos czy fala dos negros - czyli mowa gwinejska, mowa czarnych, mowa Murzynów ${ }^{8}$.

Ponowne ożywienie badań nad czarnym niewolnictwem w Europie nastąpiło na przełomie XX i XXI w. Szczególne znaczenie miała syntetyczna praca Alessandra Stelli, poświęcona niewolnictwu na Półwyspie Ibe-

${ }^{3}$ V.M. Godinho, A Economia Dos Descobrimentos Henriquinos, Lisboa 1962. Jest zastanawiające, że w swojej najbardziej znanej pracy L'Économie de l'Empire portugais aux XV ${ }^{e}$ et XVIe siècles (Paris 1969) Godinho nie zajął się handlem niewolnikami. V.C. Alonso, La trata de esclavos durante los primeros descubrimientos (1489-1516), „Anuario de Estudios Atlánticos" (Madrid), 9, 1963, s. 23-46; V.R. Rau, Notes sur la traite portugaise à la fin du $X V^{e}$ siècle et le florentin Bartolomeo di Domenico Marchionni, „Bulletin de l'Institut Historique Belge de Rome" 44,1974, s. 535-543.

${ }^{4} \mathrm{M}$. Małowist, Les débuts du système des plantations dans la période des grandes découvertes, „Africana Bulletin” 10, 1969, s. 9-30; J. L. Vogt, The Early São Tomé-Principe Slave Trade with Mina, 1500-1540, „International Journal of African Historical Studies” 6, 1973, 3, s. 453-476.

${ }^{5}$ P.E. Russell, Some Socio-Linguistic Problems concerning the Fifteenth-Century Portuguese Discoveries in the African Atlantic, w: idem, Portugal, Spain and the African Atlantic, 1343-1490, Aldershot 1995, s. 9-11; idem, Prince Henry and the Necessary End, ibidem, s. 9-10.

${ }^{6}$ A.C. de C. M. Saunders, A social history of black slaves and freedmen in Portugal 14411555, Cambridge 1982.

${ }^{7}$ J. Devisse, M. Mollat, L'Image du Noir dans l' art occidental, t. 2, Fribourg 1979.

${ }^{8}$ P. Teyssier, Le Language de Gil Vicente, Paris 1959. 
ryjskim od XVI do XIX w., a także zbiorowa praca pod redakcją Toma F. Earle'a i Kathy J. Lowe, poświęcona czarnym niewolnikom w Europie epoki Renesansu'. W obu tych książkach widoczne jest przesunięcie zainteresowań badawczych z problematyki gospodarczej ku problematyce kultury. W pracy Stelli większość materiału dotyczy społeczeństwa hiszpańskiego. Natomiast w Black Africans in Renaissance Europe opisane i zanalizowane zostało niewolnictwo głównie w Europie Południowej, w Hiszpanii, Włoszech, południowych Niemczech. Portugalii poświęcono rozdziały o niewolnikach na dworze lizbońskim, o bractwie Nossa Senhora do Rosario w Lizbonie i procesach społecznej adaptacji niewolników, o czarnych niewolnikach w południowej Portugalii, wreszcie o dziele pisarskim i życiu mulata Afonso Alvaresa. Ważny z punktu widzenia kontaktu kultur jest rozdział poświęcony europejskiej stereotypizacji poglądów na czarnych niewolników.

Celem mojego artykułu jest przeanalizowanie psychologicznych aspektów handlu afrykańskimi niewolnikami i zjawiska kontaktu kulturowego, które wynikało z obecności niewolników w Portugalii. Wybieram okres stosunkowo krótki - od początku lat czterdziestych XV w. do pierwszych lat XVI stulecia. Data początkowa, przyjęta zresztą w wielu pracach, wydaje się oczywista. W 1441 r. przywieziono bowiem do Portugalii pierwszych niewolników porwanych w Afryce. Natomiast data końcowa jest dyskusyjna. Ch. Verlinden zakończył swe dzieło na schyłku średniowiecza. Natomiast wielu wymienionych wyżej historyków i literaturoznawców badało zjawisko niewolnictwa i jego konsekwencji aż po schyłek wieku XVI, sięgając też do XVII w. Przytaczana praca zbiorowa o czarnych niewolnikach w Europie Renesansu obejmuje okres od około 1440 do około 1600 r. Trudno jednak przyjąć, że mentalność Henryka Żeglarza, jego śmiałych rycerzy wyruszających do Afryki oraz kronikarza pierwszych wypraw Gomesa Eanesa Zurary była renesansowa. Cezurą między kulturą średniowiecza a Renesansu były w Portugalii raczej dziesięciolecia przełomu XV i XVI w. ${ }^{10} \mathrm{~W}$ kontakcie kulturowym Portugalczyków i Afrykanów cezura ta miała moim zdaniem znaczenie. Praca Stelli sięga aż XIX w. i obejmuje kilka epok.

Krótszy okres interesował A.C. Saundersa. Przyjął on cezury 14411555. Tę ostatnią uzasadnił ukazaniem się w Portugalii pierwszej publikacji krytykującej okrucieństwa handlu niewolnikami i ich traktowania

${ }^{9}$ A. Stella, Histoire d'esclaves dans la Pénisule Ibérique, Paris 2000; Black Africans in Renaissance Europe, red. T. F. Earle, K. J. Lowe, Cambridge 2005.

10 Przyjmuję tu tezę Joaquima Barradasa de Carvalho, À la recherche de la spécificité de la Renaissance portugaise, t. 1-2, Paris 1983. 
ich w tym kraju ${ }^{11}$. Był to początek długiego procesu zmiany podejścia do zagadnienia niewolnictwa, ale upatrywanie w tej dacie i w tym wydarzeniu przełomu uzasadniającego cezurę badawczą wydaje się wątpliwe. Zresztą autor sięga często do wydarzeń późniejszych o dwa, trzy dziesięciolecia.

W niniejszej rozprawie przyjmuję cezurę początku XVI w. Sadzę, że właśnie wtedy nastąpiły w Portugalii w podejściu do niewolnictwa duże zmiany. Wywołane zostały one dwoma zjawiskami. Po pierwsze zagospodarowaniem bezludnej wcześniej wyspy Świętego Tomasza. Na początku XVI w.Portugalczycy stworzyli tam system niewolniczych plantacji cukrowych. Masowe zastosowanie niewolniczej siły roboczej w rolnictwie plantacyjnym zmieniło stosunek do niewolników i ich funkcji społecznych. Co więcej, system plantacyjny na São Tomé stał się wzorem dla systemu plantacji w Brazylii i innych częściach Nowego Świata. Już w latach trzydziestych XVI w. rozpoczął się masowy wywóz niewolników z Afryki do Ameryki. Cezura 1555 r. wydaje się z tego punktu widzenia zbyt późna. Krytyka niewolnictwa wywołana była w większym stopniu okrucieństwami handlu transatlantyckiego, a w mniejszym sytuacją niewolników w samej Portugalii. Z tych powodów przyjmuję cezurę pierwszych lat XVI w.

Handel niewolnikami był w dziejach Afryki zjawiskiem ogromnej wagi. Ma ono obfitą literaturę. W odniesieniu do Afryki Zachodniej badane są dwa różne okresy i typy niewolnictwa i handlu ludźmi. Od około VIII w. n.e. rozwinął się handel transsaharyjski pomiędzy arabską i berberską północą Afryki a państwami Sudanu Zachodniego. Handel niewolnikami był jedną z ważnych jego części ${ }^{12}$. Większość niewolników docierała do Maroka, Egiptu i na Bliski Wschód. Pewna ich liczba sprzedawana była do śródziemnomorskich państw chrześcijańskich. Już w XVI w. handel ten zaczął tracić na znaczeniu w stosunku do nowego zjawiska, jakim stał się niewolniczy handel transatlantycki ${ }^{13}$.

Sprowadzanie do Portugalii w XV i na początku XVI w. niewolników porywanych lub kupowanych w Afryce Zachodniej nie należało ani do

${ }^{11}$ A.C. Saunders, op. cit., s. XI-XII.

${ }^{12}$ E.W. Bovill, The Golden Trade of the Moors, Oxford 1958; M. Małowist, Le commerce de l'or et d'esclaves au Soudan Occidental, „Africana Bulletin” 4, 1966, s. 49-72; A. G. Hopkins, An Economic History of West Africa, London 1973; R. A. Austen, The Trans-Saharan Slave Trade. A Tentative Census, w: The Uncommon Market. Essays in the Economic History of the Atlantic Slave Trade, red. H. A. Gemery, J. S. Hogendorn, New York 1979, s. 23-76.

${ }^{13}$ R.A. Austen, op. cit.; B. Nowak, Handel niewolnikami, w: Historia Afryki do poczatku XIX w., red. M. Tymowski, Wrocław 1996, s. 1168-1230, tam dalsza, bardzo obszerna literatura. 
pierwszego z wymienionych zjawisk (handlu transsaharyjskiego), ani do drugiego (handlu transatlantyckiego). Wprawdzie działalność Portugalczyków oddziaływała na oba wymienione typy wymiany handlowej, ale niewolniczy handel portugalski w XV w. stanowił zjawisko odrębne. Jego rozmiary i rola w gospodarce międzyregionalnej i globalnej były niewielkie. Stąd być może traktowanie go jako preludium do handlu transatlantyckiego. Wybierając cezurę początku XVI w., pragnę podkreślić, że handel niewolnikami afrykańskimi w Portugalii w XV i na początku XVI w. był zjawiskiem mającym swoiste cechy, warte rozpatrzenia same w sobie. A także, że poza zbadanym już gospodarczym i społecznym aspektem miał on odrębny aspekt psychologiczny i kulturowy.

W badaniu kontaktu kulturowego dwóch odrębnych grup ludzkich wielkie znaczenie ma liczebność każdej z tych grup ${ }^{14}$. Wiemy, że liczba ludności Portugalii wynosiła w połowie XVI w. około miliona. Natomiast liczbę niewolników - przymusowych przybyszów z Afryki do Portugalii - możemy określić tylko hipotetycznie. Materiały statystyczne są bowiem wyrywkowe, a dokumentacji brak ciągłości. Ponadto liczba ta ulegała zmianom między $1441 \mathrm{r}$. a początkiem XVI w. - od niewielkich grup niewolników w latach czterdziestych wzrosła do prawdopodobnie kilku tysięcy rocznie przywożonych w końcu XV w.

Kronikarz Zurara oceniał, że od początku wypraw do roku 1448, na którym zakończył swoje dzieło, przywieziono z Afryki 927 niewolników ${ }^{15}$. W następnych latach intensywność przywozu niewolników wzrastała. Jedna tylko wyprawa Wenecjanina Alvise da Ca da Mosto pozwoliła mu w 1455 r. na zakup w Afryce stu ludzi. Ca da Mosto ocenił cały import niewolników w latach pięćdziesiątych XV w. na 800 do 1000 rocznie $^{16}$. W latach osiemdziesiątych i dziewięćdziesiątych XV w. liczba niewolników sprowadzanych do Portugalii z Afryki była już znacznie większa. Rachunki zarządcy (almoxarife) Casa dos Escravos w Lizbonie Johama do Porto

${ }^{14}$ R. Redfield, R. Linton, M.J. Herskovits, Memorandum for the Study of Acculturation, „American Anthropologist. New Series” 37, 1936, 1, s. 149-152; K. Kwaśniewski, Zderzenie kultur. Tożsamość a aspekty konfliktów i tolerancji, Warszawa 1982, s. 35-40.

${ }^{15}$ G. E. de Zurara, Crónica dos feitos notáveis que se passaram na conquista de Guiné por mandado do Infante D. Henrique, oprac. T. de Sousa Soares, t. 2, Lisboa 1981, s. 549 (dalej cytuję Zurara-Soares). Najczęściej cytowane tłumaczenie francuskie - G. E. de Zurara, Chronique de Guinée, przedm. L. Bourdon, Dakar 1960, s. 265 (dalej cytuję Zurara-Bourdon).

${ }^{16}$ Le navigazioni atlantiche del Veneziano Alvise Da Mosto, red. T. Gasparrini Leporace, Roma 1966, Il Nuovo Ramusio, t. 5, s. 27 (dalej cytuję Ca da Mosto-Leporace). Patrz też $\mathrm{W}$. Brulez, Les voyages de Cadamosto et le commerce guinéen au XVe siècle, „Bulletin de l'Institut Historique Belge de Rome” 39, 1968, s. 311-326, liczby niewolników s. 318-320. 
świadczą, że od 15 czerwca 1486 r. do 31 grudnia 1493 r. przywieziono „z Gwinei” do Lizbony 3589 niewolników. Z kolei florentyńczyk Bartolomeo Marchionni, który wykupił od korony prawa do handlu w Afryce, sprowadził w latach 1489-1490 i 1493-1495 wedle oceny Verlindena 1648 niewolników ${ }^{17}$. Liczby te są wyrywkowe, pozwalają jednak przyjąć, że import niewolników z Afryki wynosił w ostatnich dziesięcioleciach XV w. do dwóch tysięcy rocznie, jednakże wahania były znaczne, wedle Saundersa od 300 do 2000 niewolników ${ }^{18}$. Ponieważ nie wszyscy przywożeni z Afryki niewolnicy trafiali do Portugalii, część wywożona była do innych królestw, głównie do Kastylii, ogólną liczebność czarnych niewolników w samej Portugalii ocenia się na około 10 tysięcy. Dodać do tego trzeba pewną liczbę niewolników białych. Łącznie na przełomie XV i XVI w niewolnicy stanowili ponad 1\% ludności Portugalii ${ }^{19}$. A.C. Saunders zbadał nie tylko liczebność, ale i rozmieszczenie niewolników. Przy badaniu kontaktu kulturowego między Portugalczykami a ich afrykańskimi niewolnikami pamiętać musimy o skupieniu tych ostatnich w miastach. Procent ludności niewolniczej zdecydowanie przekraczał tam ogólną przeciętną. Saunders oblicza, że w latach trzydziestych i czterdziestych XVI w. niewolnicy stanowili blisko 10\% ludności Lizbony i tyleż Evory ${ }^{20}$. Tam właśnie miały miejsce najbardziej intensywne kontakty.

Kronikarz Zurara obszernie opisał przywiezienie do Lagos w 1444 r. pierwszego dużego transportu niewolników afrykańskich. Chociaż przywożono ich już wcześniej, ten transport ze względu na liczbę ludzi i okoliczności ich wyładunku, zrobił na kronikarzu i na miejscowej ludności ogromne wrażenie. Tekst ten jest znakomitym przykładem psychicznych napięć i emocji wywołanych przez handel niewolnikami. Interesujący nas fragment kroniki był wielokrotnie cytowany. Uczynił to również Verlinden ${ }^{21}$. Jego komentarz jest bardzo celny, ale zwięzły. Wątku psychologicznego analizy nie podjął on w dalszej części swojej pracy być może dlatego, że w latach pięćdziesiątych XX w. psychohistoria nie była jeszcze ważnym działem historiografii ${ }^{22}$. Inni badacze analizowali ten fragment jako opis

${ }^{17}$ Ch. Verlinden, op. cit., s. 625-627.

${ }^{18}$ A.C. Saunders, op. cit., s. 19-27.

${ }^{19}$ Ibidem, s. 50-58.

${ }^{20}$ Ibidem, s. 51, 54-57.

${ }^{21}$ Ch. Verlinden, op. cit., s. 618-619.

${ }^{22}$ Początek dał tym badaniom już Lucien Febvre, La sensibilité et histoire. Comment reconstituer la vie affective d'autrefois, „Annales d'histoire sociale” 1941, 3, s. 5-20; na- 
wyjątkowo dramatycznego, jednorazowego wydarzenia, a nie jako początku procesu dokonującego się w kontaktach między Afrykanami i Portugalczykami. Odwoływano się raczej do empatii czytelnika, niż analizowano znaczenie tego tekstu ${ }^{23}$.

Fragment ten, chociaż jest już w literaturze cytowany, wymaga przytoczenia także tutaj, gdyż żaden opis nie może oddać szczególnego napięcia wyrażonego przez Zurarę ${ }^{24}$. Gdy karawele dowodzone przez Lançarote'a powróciły z Afryki i dotarły do Lagos, kapitanowie udali się na ląd, by zdać relację z wyprawy. Nazajutrz Lançarote powiedział księciu Henrykowi: „Panie, Wasza Łaskawość wie, że należy mu się kwinta od tych Maurów i od wszystkiego, co uzyskaliśmy w tych ziemiach, do których posłałeś nas w służbie Boga i Waszej Wysokości. Ale ci Maurowie, ze względu na długi czas, który spędziliśmy na morzu, i na smutek, który odczuwają w swych sercach - jak to możecie sobie wyobrazić bo znajdują się tak daleko od ich rodzinnych krajów, obróceni są w niewolę i nie znają losu, który ich oczekuje; także ze względu na ich nieprzyzwyczajenie do pływania statkiem - otóż ci Maurowie, powiadam, przybyli w bardzo złym stanie i bardzo chorzy. Sądzę wiec, że będzie lepiej, jeśli nakażecie ich wydobyć z karawel jutro rano". Tak się też stało. Opis podziału niewolników zaczął Zurara od modlitwy „O Ty, Ojcze Niebieski, który swa wszechmocną ręką i w niewzruszeniu Twych cech boskich, rządzisz niezliczonymi ludami! [- - ] Błagam Cię, aby me łzy nie zmąciły mej świadomości, bo nie myśląc o religii tych ludzi, ale myśląc, że są to właśnie ludzie - jak ja jestem człowiekiem - mogę tylko płakać z litości nad ich cierpieniami! I jeśli srogie bestie z ich bestialskimi odczuciami mają poprzez naturalny instynkt świadomość nieszczęść bestii im podobnych, cóż ma uczynić moja natura ludzka, gdy mam przed oczami tę grupę nieszczęsną i gdy pomyślę, że są to [także] potomkowie Adama?"25.

stępnie A. Dupront, Problèmes et méthodes d'une histoire de la psychologie collective,„Annales. Economies, Sociétés, Civilisations" 33, 1961, fasc. 1, s. 3-10; G. Duby, Histoire des mentalités, w: L'Histoire et ses méthodes, red. Ch. Samaran, Paris 1961, s. 937-966; R. Mandrou, L'Histoire des mentalités, w: Encyclopaedia universalis, t. 8, Paris 1968, s. 436-438; J. Le Goff, Les Mentalités, une histoire ambiguë, w: Faire de l'histoire, red. J. Le Goff, P. Nora, Paris 1974, t. 3, s. 76-94; H. Martin, Mentalités médiévales, XIe-XVe siècle, Paris 1996. W Polsce patrz B. Geremek, Umysłowość i psychologia zbiorowa w historii, PH 53, 1962, 4, s. 629-644.

${ }^{23}$ P.E. Russell, Prince Henry the Navigator, w: idem, Portugal, Spain and the African Atlantic, s. 25-26; M. Małowist, Europa a Afryka Zachodnia w dobie wczesnej ekspansji kolonialnej, Warszawa 1969, s. 122-124; w formie popularnej: M. Tymowski, Ludzie czy „sztuki”?, „Mówią Wieki” 1969, 11, s. 40.

${ }^{24}$ Całość opisu: Zurara-Soares, s. 142-152; Zurara-Bourdon, s. 108-112.

${ }^{25}$ Zurara-Soares, s. 142-145: „Senhor: bem sabe a Vossa Mercê como haveis de 
Zurara był panegirystą Henryka Żeglarza, ale scena podziału zdobyczy musiała nim głęboko wstrząsnąć, skoro zdobył się na te i następne słowa: „Rankiem, 8 dnia sierpnia, bardzo wcześnie ze względu na upał, marynarze rozpoczęli przygotowywać łodzie, umieszczać na nich niewolników i przewozić ich tam, gdzie im kazano. Ludzie ci, zebrani na placu, tworzyli zadziwiający widok. Byli między nimi niektórzy prawie biali, o przyjemnym wyglądzie, proporcjonalnie zbudowani, inni mniej biali, tak jak Mulaci, a jeszcze inni ciemni jak Etiopowie i tak brzydcy na ciele i twarzy, że zdawali się pochodzić z podziemnego padołu. Ale czyż jest serce tak twarde, aby nie przeniknęło go uczucie żałości na widok tych ludzi? Oto jedni z nich z głowami opuszczonymi i zalani łzami spoglądali nawzajem na siebie, inni, jęcząc boleśnie, obracali oczy ku niebu, jakby prosili o pomoc Ojca natury, inni bili się rękoma po twarzy i rzucali na ziemię. Byli tacy, którzy śpiewali smutne pieśni i chociaż słowa ich języka nie są zrozumiałe, pieśni owe dobrze ukazywały ich nieszczęście. I oto, aby jeszcze zwiększyć ich cierpienia, pojawili się ci, którym rozkazano podzielić jeńców. Zaczęto ich dzielić na grupy tak, aby części były równe, więc trzeba było rozłączyć dzieci od rodziców, żony od mężów, brata od brata. Niczego nie brano pod uwagę i ludzi przydzielano tam, gdzie wypadło [--]. Wy, co jesteście tak zajęci podziałem jeńców, miejcie litość dla ich wielkiego nieszczęścia, popatrzcie na tych ludzi chwytających się wzajemnie, nie dających się rozdzielić. Czy możliwe jest dokonać takiego podziału bez trudu? Kiedy umieszczono ich w jakiejś grupie, dzieci wyrywały się całą siłą do rodziców, biegły do nich, matki obejmowały swe dzieci i chroniły je własnym ciałem, godząc się raczej na śmierć niż na odebranie im dzieci. I tak, nie bez trudu, dokonano rozdzielenia. Bo obok oporu, który stawiali niewolnicy, cały

haver o quinto destes mouros e de tudo o que ganhámos em aquela terra, onde por serviço de Deus e vosso nos mandastes. Mas, agora, estes mouros, pelo grande tempo que há que andámos no mar como também pelo nojo que deveis considerar que terão em seus corações, vendo-se fora da terra de sua naturalidade e postos em cativeiro sem haver qualquer conhecimento de qual será seu fim; depois, a usança que não hão de andar em navios; por tudo isto, vêm assaz mal dispostos e doentes. Pelo que me prece que será bom que, de manhã, os mandeis tirar das caravelas [- - ]. ó Tu, Celestal Pai, que, com Tua poderosa mão sem movimento, de Tua divinal essência governas toda a infinida companhia da Tua santa cidade [- - ]. Eu Te rogo que as minhas lágrimas não sejam dano da minha consciência: porque, não por sua lei, destes, mas a sua humanidade constrange a minha [a] que chore piedosamente o seu padecimento. E se as brutas animálias com seu bestial sentir, por um natural instinto, conhecem os danos de seus semelhantes, que queres que faça esta minha humana naturaleza, vendo assim ante os meus olhos esta miserável companha, [e] lembrando-me que são da geração dos filhos de Adão?!”. (Wszystkie fragmenty kroniki Zurary w tłumaczeniu M. Tymowskiego). 
plac zapełnił się ludźmi z miasta, wsi i okolic, którzy dnia tego nie wykonywali pracy, z której żyli, gdyż chcieli przyjrzeć się niezwykłemu widowisku. Ale widząc jednych zapłakanych, a drugich rozdzielających jeńców, obserwatorzy wszczęli taki tumult, aż zmieszali się i zawstydzili ludzie organizujący ten podział. Był tam w asyście świty infant, dosiadający wspaniałego rumaka i darzący innych swoimi łaskami, który jako człowiek mało dbający o zatrzymanie swojej części, z 46 dusz tworzących jego kwintę dokonał nowego podziału [rozdzielając dary]"26.

Pociechą była dla kronikarza świadomość, że ważniejsze od cierpień niewolników było zbawienie ich dusz: ,gdy tylko bowiem ci jeńcy nabrali pewnej znajomości naszego języka, trzeba było niewiele starań, aby zostali

${ }^{26}$ Zurara-Soares, s. 146-148: „No outro dia, que eram 8 dias do mês de Agosto, muito cedo pela manhã, por razão da calma, começaram os mareantes de aparelhar seus batéis e [de] tirar aqueles cativos para os levarem, segundo lhes fora mandado. Os quais postos juntamente naquele campo, era uma maravilhosa coisa de ver: porque entre eles havia alguns de razoada brancura, formosos e apostos; outros, menos brancos, que queriam semelhar pardos; outros tão negros como Etiópios, tão desafeiçoados assim nas caras como nos corpos que quase parecia aos homens que os esguardavam que viam as imagens do hemisfério mais baixo. Mas qual seria o coração, por duro que ser pudesse, que não fosse pungido de piedoso sentimento vendo assim aquela companha? Porque uns tinham as caras baixas e os rostos lavados com lágrimas, olhando uns contra os outros; outros estavam gemendo mui dolorosamente, esguardando a altura dos céus, firmando os olhos em eles, bradando altamente como se pedissem socorro ao Pai da Natureza; outros feriam seu rosto com suas palmas, lançando-se estendidos em meio do chão; outros faziam suas lamentações em maneira de canto, segundo o costume de sua terra, aos quais (posto que as palavras da linguagem aos nossos não pudesse ser entendida) bem correspondiam ao grau de sua tristeza. Mas para seu dó ser mais acrescentado, sobrevieram aqueles que tinham cargo da partilha, e começaram de os apartar uns dos outros a fim de porem seus quinhões em igualdade. Pelo que convinha de necessidade se apartarem os filhos dos pais; e as mulheres, dos maridos; e os irmãos, uns dos outros. A amigos nem a parentes, não se guardava nenhuma lei; sòmente, cada um caia onde a sorte o levava [- - ]. E vós outros, que vos trabalhais de [fazer] esta partilha: esguardai com piedade sobre tanta miséria, e vêde como se apertam uns aos outros que mal os podeis desligar. Quem poderia acabar aquela partição sem mui grande trabalho? Pois, logo que os tinham posto numa parte, os filhos que viam os pais na outra levantavam-se prestamente e iam-se para eles; as mães apertavam os outros filhos nos braços e lançavam-se com eles de bruços, recebendo feridas, com pouca piedade de suas carnes, para lhes não serem tirados. E assim trabalhosamente os acabaram de partir; porque, além do trabalho que tinham com os cativos, o campo era todo cheio de gente, assim do lugar como das aldeias e comarcas derredor, os quais deixavam em aquele dia folgar suas mãos em que restava a força do seu ganho, sòmente por ver aquela novidade. E com estas coisas que viam, uns chorando, outros falando, faziam tamanho alvoroço que punham em torvação os governadores daquela partilha. O Infante era ali, em cima de um poderoso cavalo, acompanhado de suas gentes, repartindo suas mercês como homem que de sua parte queria fazer pequeno tesouro. Porque de 46 almas que aconteceram no seu quinto, mui breve fez deles sua partilha". 
chrześcijanami”. I dodawał „następnie poznawali oni kraj, w którym odkryli wielką obfitość bogactw i w którym traktowani byli bardzo łaskawie. Bo widząc, że nie są zatwardziali w wierze innych Maurów i że przyjmowali ze szczerym sercem religię chrystusową, ludzie nie czynili żadnej różnicy między nimi (niewolnikami) i wolnymi służącymi urodzonymi w kraju"27.

Niewolnicy zostali ochrzczeni i uratowali dusze, co usprawiedliwiało w oczach Zurary postępowanie Henryka Żeglarza i jego otoczenia. Ale widok wycieńczonych jeńców i ogrom ich nieszczęścia, a szczególnie dzielenie rodzin, wywołały protesty zwykłych ludzi, obserwujących wydarzenie. Doszło do tumultu. Nawet oprawcy „czuli się zmieszani”. Infant Henryk zdołał przywrócić porządek i dokonać planowanego podziału. W tej scenie zderzyły się więc ludzka rozpacz niewolników z ludzkim współczuciem zwykłych mieszkańców Lagos i z ludzką chciwością i okrucieństwem otoczenia infanta. Pojawiła się ponadto - już na początku przywozu niewolników z Afryki - łatwość tłumaczenia cudzych cierpień i własnych bezwzględnych czynów dobrem wyższym. Przerażeni zwykli ludzie, nieczerpiący z procederu żadnych korzyści, dali wyraz swojemu współczuciu. Podobne uczucie przeniknęło kronikarza Zurarę tak silnie, że nie mógł pominąć go w swoim dziele.

Zurara był prawdopodobnie świadkiem tej sceny. Opisał nie tylko wybuch emocji, ale także wygląd porwanych Afrykanów. Kronikarz dostrzegł w nich przede wszystkim ludzi, ,potomków Adama”. Zobaczył więcej - ich zróżnicowane cechy wynikające z rasy, wyglądu, płci i wieku. Dostrzegł - wedle własnych kryteriów - piękno i brzydotę. Większość tych kryteriów będzie w przyszłości używana w ocenie wartości niewolników. Lecz w momencie rozegrania się tej sceny było to doświadczenie ukazujące obserwatorom różnorodność rodzaju ludzkiego.Czarnych niewolników znano w świecie śródziemnomorskim od starożytności i poprzez całe średniowiecze ${ }^{28}$. W tym wypadku obserwacja grupy około 230240 osób pozwalała na więcej wniosków, była doświadczeniem nowym.

W omawianym tu fragmencie kroniki Zurary jest jeszcze jeden passus wymagający komentarza, mianowicie słowa Lançarote'a dotyczące złego

${ }^{27}$ Zurara-Soares, s. 148, 149: „pois [- - ] como já dissemos, logo que haviam conhecimento da linguagem, com pequeno movimento se tornavam cristãos”; „[posto isso] foram eles porém ao diante havendo conhecimento da terra, na qual achavam grande abastança, e além disso [conhecimento de] como os tratavam com grande favor. Pois, porque as gentes os não achavam endurentados na crença dos outros mouros e viam que, de boa vontade, vinham para a lei de Cristo, não faziam de eles diferença [em ralação] aos servidores livres naturais da própria terra".

${ }^{28}$ F. M. Snowden, Black in Antiquity, Cambridge, Mass. 1970; I. Bieżuńska-Małowist, M. Małowist, Niewolnictwo, Warszawa 1987, s. 46, 55-57, 320-324. 
stanu psychicznego i zdrowotnego niewolników, wynikającego z porwania, nagłej zmiany sytuacji, uciążliwej podróży morskiej, strachu i rozpaczy.Jest to jedyny tekst pochodzący z XV w. świadczący o warunkach przewożenia niewolników, w którym mówi się ponadto o rozpaczy tych ludzi.

P.E. Russell $w$ artykule dotyczącym piętnastowiecznych relacji naocznych świadków odkryć zwrócił uwagę na to, że A. da Ca da Mosto, Antoniotto Usodimare i Eustachy Delafosse nie napisali ani słowa o przewozie niewolników do Portugalii ${ }^{29}$. A przecież każdy z nich kupował w Afryce niewolników i o kupowaniu pisał bez zahamowań. Od chwili załadowania ludzkiego towaru na karawele niewolnicy w opisach zanikają. Jedyną wzmiankę pozostawił Delafosse, pisząc o niewolnicy, która skoczyła do morza, by dopłynąć do rodzinnego brzegu w Sierra Leone, została jednak doścignięta przez szalupę wysłaną w pogoń ${ }^{30}$.

Jeśli chodzi o milczenie podróżników i kupców w sprawie warunków przewozu niewolników, prawdopodobne jest, że był to temat bardzo drażliwy i nie mieli oni ochoty dzielić się swą wiedzą z czytelnikami. Przypomnijmy, że karawele były statkami małych rozmiarów, ich załogi liczyły 20-30 osób ${ }^{31}$. Jeśli stłoczono na małej karaweli od 30 do 50 niewolników, a wedle Saundersa nawet 120 na dużej karaweli, a 150 na nawie, warunki ich przewozu musiały być okropne. Część niewolników umierała, zanim dopłynięto do Portugalii.

Zurara pocieszał się nie tylko uratowaniem dusz ochrzczonych niewolników. Uważał również ich życie w Portugalii za lepsze niż w Afryce. Wspominał - jak przytoczyliśmy - że traktowano ich dobrze, podobnie jak wolną służbę. Uratowano nie tylko ich dusze, ale także ciała. „Gdyż żyli oni [poprzednio] jak zwierzęta, nie postępując jak rozumne istoty. Nie znali oni ani chleba, ani wina, nie umieli ani okrywać się tkaninami, ani zamieszkiwać w domach. I gorsza jeszcze była ich ignorancja uniemożliwiająca jakąkolwiek znajomość dobra i skłaniająca ich do życia bestialskiego. Gdy tylko przybyli do naszego kraju, dano im gotowane pożywienie oraz ubrania dla okrycia ich ciał. Ale ich brzuchy zaczęły [od tego pożywienia] puchnąć i często chorowali, bo nie byli przyzwyczajeni do naturalnych warunków panujących w naszej ziemi. Niektórzy z nich

${ }^{29}$ P.E. Russell, Veni, vidi, vici. Some Fifteenth-century Eyewitness Accounts of Travel in the African Atlantic before 1492, w: Medieval Ethnographies. European Perceptions of the World Beyond, red. J.-P. Rubiés, Asghate 2009, s. 315-328, o braku informacji s. 323.

${ }^{30}$ Voyage d'Eustache Delafosse sur la côte de Guinée, au Portugal et en Espagne (14791481), wyd. D. Escudier, Paris 1992, s. 39.

${ }^{31}$ P. Chaunu, L'expansion européenne du XIII au XVe siècle, Paris 1969, s. 284-288; A.C. Saunders, op. cit., s. 11. 
byli w takim stanie, że nie mogli znieść nowych warunków i umierali, ale przynajmniej umierali jako chrześcijanie"32.

Dobrodziejstwa znalezienia się i życia w niewoli były więc względne, nawet zdaniem Zurary. Nie ustawał on jednak w przekonywaniu samego siebie i swoich czytelników, że Afrykanom świadczono dobro. Oceniał, że „Maurowie" schwytani w Afryce Zachodniej różnili się bardzo od Maurów z Afryki Północnej. „Po pierwsze, gdy raz znaleźli się w naszym kraju, nigdy nie starali się uciec, często zapominali o swojej ziemi i zaczynali odczuwać zalety naszej. Po drugie, byli bardzo lojalnymi i posłusznymi sługami i nie dawali nigdy dowodów złości. Po trzecie, nie oddawali się, jak inni, lubieżności. Po czwarte, gdy tylko zaczęli używać ubrań, stawali się najczęściej bardzo kokieteryjni i dobierali sobie tkaniny o jaskrawych kolorach [- - ]. Ale co najważniejsze, że ze szczerym sercem, jak już było powiedziane, przyjmowali drogę wiary [- - ], w której dożywali do śmierci" ${ }^{33}$.

Przytoczony powyżej tekst można też uznać za swoisty program postępowania wobec niewolników. Był to - przyjąwszy współczesną terminologię - program akulturacji. Zurara nie wyrażał przy tym swoich indywidualnych poglądów, raczej poglądy swojego środowiska, czyli dworu królewskiego i otoczenia infanta Henryka.

Bez wątpienia na dworze infanta chrzczenie pogan uważano za najważniejszy cel, choć przecież niejedyny. Poczucie wyższości własnej kultury czerpano właśnie z bycia chrześcijanami. Afrykanom przypisywano niższość, nawet bestialstwo, wynikające z pogaństwa. Konsekwencją takiego rozumowania była możliwość włączenia do własnej wspólnoty ludzi, którzy zostali ochrzczeni. Będąc niewolnikami, mogli oni znajdować się na dole struktury społecznej, ale jako jej członkowie.

32 Zurara-Soares, s. 150-152: ,por viverem, assim, como bestas, sem qualquer preceito de criaturas racionais. Porque eles não sabiam que era pão nem vinho, nem cobertura de pano, nem alojamento de casa; e o pior, era a grande ignorância que em eles havia, pela qual não haviam qualquer conhecimento de bem; sòmente [sabiam] viver em uma ociosidade bestial. E logo, como començavam de vir a esta terra e lhes davam os mantimentos artificiais e as coberturas para os corpos, começavam de lhes crescer os ventres e, por tempos, eram enfermos até que se reformavam com a natureza da terra; em o que alguns deles eram tão compleicionados que o não podiam suportar, e morriaram, todavia cristãos".

${ }^{33}$ Ibidem: ,a primeira, que depois que eram em esta terra nunca mais se trabalhavam de fugir, antes, com o tempo se esqueciam, de todo, da sua [terra], logo que começavam [a] sentir as bondades de esta; e a segunda, que eram muito leais e obedientes servidores sem malicia; e a terceira, que não eram tão chegados à luxúria como os outros; e a quarta, que depois que usavam os vestidos eram geralmente muito louçãos de vontade, pelo que folgavam muito com roupas de cores divisadas [- - ]. E o melhor era, como já tenho dito, que se tornavam de boa vontade ao caminho da Fé, na qual [- ] faziam seus finis". 
Opinie Zurary o losie afrykańskich niewolników możemy zweryfikować nawet na podstawie innych fragmentów jego kroniki, ale przede wszystkim dzięki analizie innych źródeł. O poczuciu nieszczęścia i chęci odzyskania wolności świadczą ucieczki niewolników. Najwcześniejszym przykładem jest los niewolnika Adahu, Berbera pochwyconego w $1441 \mathrm{r}$. przez wyprawę dowodzoną przez Nuno Tristão. Adahu wywodził się ze szlachetnego rodu, wiadomości przez niego przekazane uznano za cenne. Obdarowano go sowicie. Pomimo dostatków pragnął odzyskać wolność. Zurara odnosił się do tego ze zrozumieniem, pisząc, że „każdy niewolnik odczuwa naturalne pragnienie bycia wolnym". Adahu prosił żeglarza Antão Gonçalvesa o odwiezienie go do kraju, ofiarowując w zamian pięciu-sześciu niewolników. Dwaj inni ujęci w 1441 r. obiecali po dwóch niewolników za swą wolność. Uzyskano by więc dziesięciu ludzi za trzech. Henryka Żeglarza przekonano, że lepiej uratować dziesięć dusz niż trzy. W 1443 r. karawele dotarły do okolic wybrzeża (przy Rio de Ouro), gdzie porwano Adahu. Ten ostatni miał służyć za tłumacza i nawiązać kontakt z Berberami z lądu. Udało się rozpocząć handel, ale Adahu wysłany na brzeg nie powrócił na karawelę, „nie dotrzymał słowa, niepomny na dobrodziejstwa, [których doznał]"34.

W czasie innej wyprawy w 1443 r. do Przylądka Białego i wyspy Arguim uciekł inny tłumacz - niewolnik służący na karaweli Gonçalo da Sintra $^{35}$. Widocznie „dobrodziejstwa” nie rekompensowały niewolnikom utraty wolności.

W połowie lat pięćdziesiątych XV w., gdy do Afryki podróżował Ca da Mosto, tłumacze już nie uciekali. Być może zaostrzono ich kontrolowanie, być może władcy afrykańscy, jak Budomel, z którym handlował Wenecjanin, też potrzebowali usług tłumaczy, więc uniemożliwiali im ucieczkę ${ }^{36}$. Możliwe też, że w miarę upływu lat i przyzwyczajania się niewolników do życia w Portugalii pragnienie wolności i powrotu do swoich słabło.

Sytuacja tłumaczy-niewolników była zupełnie wyjątkowa. Większość z nich wieziono karawelami do Afryki, i to do tych odcinków wybrzeża, z których sami się wywodzili. Zwiększało to szanse powodzenia ucieczki. Inni niewolnicy przywiezieni do Portugalii nie mieli prawie żadnych możliwości przedostania się do Afryki, chyba że służyli na karawelach

${ }^{34}$ Zurara-Soares, s. 103, 107; Zurara-Bourdon, s. 90-93. „Como sabeis, naturalmente todo preso deseja ser livre [- - ]. [o mouro cavaleiro] nunca tornou a satisfazer a sua menagem, nem tão pouco se lembrou do beneficio".

${ }^{35}$ Zurara-Soares, s. 157; Zurara-Bourdon, s.114.

${ }^{36}$ Ca da Mosto-Leporace, s. 49-50; M. Tymowski, How did European Explorers Communicate with Indigenous African People in the $15^{\text {th }}$ Century?, „Africana Bulletin” 50, 2002, s. 43-74, uniemożliwianie ucieczek s. 54. 
jako członkowie załogi. Jednakże Pero Negro, niewolnik, o którym będzie jeszcze mowa, uciekł z kilkoma innymi barką do Maroka. Jeśli niewolnicy uciekali od właścicieli, to ukrywali się przede wszystkim w Portugalii lub w Kastylii. Spośród ponad 150 dokumentów dotyczących niewolników umieszczonych w Portugaliae Monumenta Africana (PMA), ucieczek dotyczy zaledwie 10 dokumentów ${ }^{37}$. Były to więc albo wydarzenia sporadyczne, albo - co bardziej prawdopodobne - uciekiniera znajdowano tak szybko, że nie powstawała konieczność wdrażania procedury prawnej. Ucieczki pojawiają się w dokumentach stosunkowo późno. Pierwsza wzmianka z 1488 r. dotyczy zresztą sytuacji skomplikowanej - jest to akt łaski króla Jana (João) II dla João de Castanheira, mieszkańca Madery, który umożliwił ucieczkę cudzemu niewolnikowi, João Penteado, zesłanemu na Wyspę Świętego Tomasza.

Nie mniej skomplikowana była sytuacja opisana w dokumencie z 12 maja 1493 r. Jest to polecenie wyzwolenia czarnego niewolnika Pero Negro, pochodzącego z Cabo da Guiné, który uciekł najpierw do Fezu, ale potem powrócił do Królestwa Portugalii, bo czuł się chrześcijaninem i nie chciał stracić wiary ${ }^{38}$.

Inne dokumenty świadczące o ucieczkach pochodzą z 1495 (dwa), 1496, 1497, 1500 (dwa), 1501 i 1502 r. Poza jednym są to upoważnienia do odebrania zbiegów wystawione przez właścicieli innym osobom. Być może byli to ludzie wysyłani w pogoń za uciekinierami. Większość tych dokumentów pochodzi z protokołów notarialnych Sewilli. Świadczą one o silnych związkach między Sewillą i Portugalią. Dwóch uciekinierów (protokoły z lat 1495 i 1500) uciekło do Portugalii i tam ich ścigano. O dwóch innych uciekinierach (protokoły z lat 1496 i 1500) napisano, że mówili po portugalsku. Spośród nich portugalskojęzyczny niewolnik Anton uciekł w 1496 r.nie do Portugalii, ale do Kordoby.

W protokołach zawsze podawano imiona niewolników, płeć, kolor skóry i wiek. Ten ostatni mieścił się między 28 a 35 laty, brak zbiegów bardzo młodych i starszych, nie ma wśród nich ani jednej kobiety. W dwóch wypadkach właściciel niewolnika upoważniał swego plenipotenta nie tylko do odebrania, ale i do sprzedania ujętego zbiega (1497 i 1502), widocznie przewidując dalsze ucieczki i kłopoty.

${ }^{37}$ Portugaliae Monumenta Africana, wyd. L. de Albuquerque, M.E. Madeira Santos, t. 1-3, 5, Lisboa 1993-1995 (dalej cytuję PMA), dokumenty: 1/212 z 1488 r.; 2/58 1493, $107-1495,114-1495,153-1496,164-1497 ; 3 / 24-1500,50-1500,90-$ $1501,130-1502$.

${ }^{38}$ PMA, 2/58, ,que vemdo elle que era cristão e nom queria leixar a fee de Nostro Senhor Jesuu Cristo se tornara a estes nosos regnnos", wystawcą był doktor Rui Boto, dziekan na Uniwersytecie w Coimbrze. 
Dokumenty te pochodzą z lat dziewięćdziesiątych XV i z początku XVI w. Utwierdza nas to w przekonaniu, że ogromna większość ucieczek kończyła się szybko i nie była rejestrowana. Możliwe jest jednak i inne tłumaczenie - zaginięcie dokumentów portugalskich w czasie trzęsienia ziemi w Lizbonie (1755). Brak dokumentów sprzed 1488 r. i pojawienie się ich w następnej dekadzie może być świadectwem zmiany sytuacji zbiegów. Gdy w latach 1440-1480 niewolników było niewielu, ich schwytanie odbywało się szybko i łatwo. Gdy zaś liczba czarnych niewolników znacznie wzrosła i gdy pojawili się wyzwoleńcy, czyli ludzie wolni rasy czarnej, możliwości ucieczki i ukrycia się zbiegów, stwarzania pozoru legalności pobytu w danym miejscu, stały się większe. Ucieczkom mógł też sprzyjać tryb życia niewolników, którym pozostawiano pewną swobodę. Wiele wskazuje na to, że poziom ich życia zbliżał się do poziomu życia wolnej służby i ogólnie do życia wolnych ludzi z niższych warstw społecznych. Swoboda życia niewolników wywoływała nawet przeciwdziałanie władz.

Z 22 marca 1502 r. pochodzi rozporządzenie wydane w imieniu króla Manuela Szczęśliwego zakazujące niewolnikom i niewolnicom czarnym i białym jeść i pić w karczmach, sklepach i innych miejscach tego typu, zarówno publicznych, jak i prywatnych, w Lizbonie i w miejscowościach okolicznych. Zakaz obwarowano karą grzywny dla karczmarzy i sklepikarzy, nadto nakazano zamykanie tawern nocą ${ }^{39}$.

Ogromną większość zawartych w PMA dokumentów dotyczących niewolników stanowią akty ich sprzedaży. Sporządzano je według stałego formularza. Zapisywano kto, komu i za ile sprzedał niewolnika, podawano jego imię, płeć, kolor skóry, wiek i miejsce pochodzenia w Afryce lub urodzenia w Europie. Podobny formularz stosowano w zbiorczych zestawieniach niewolników sprzedanych w konkretnych miesiącach lub latach. Jeżeli byli to ludzie przywiezieni właśnie z Afryki, jeszcze nieochrzczeni, nie podawano ich imion, informowano tylko, skąd statek ich przywiózł i jaka była ich liczba.

Celem naszym, przypomnijmy, nie jest badanie niewolnictwa jako zjawiska ekonomicznego, ale jako formy kontaktu kulturowego i zjawiska z zakresu psychologii historycznej.

Przytłaczająca większość imion sprzedawanych kobiet, mężczyzn i dzieci była chrześcijańska ${ }^{40}$. Chrztu i nadania imienia dokonywano po przywiezieniu pojmanego do Portugalii. Już Zurara wspomniał, że sta-

${ }^{39}$ PMA, 3/146.

${ }^{40}$ Studium imion niewolniczych przeprowadził José Leite de Vasconcelos, Antroponimia Portuguesa, Lisboa 1928, s. 361-381. 
rano się odłożyć ceremonię do czasu, gdy niewolnik nauczy się choć trochę języka portugalskiego i będzie rozumieć sens chrztu. Imię wybierał prawdopodobnie właściciel niewolnika, zgodnie z obowiązującą modą. W ostatnich dwóch dziesięcioleciach XV w. i w pierwszej dekadzie XVI w. najczęściej nadawanym imieniem żeńskim była Catalina, na drugim miejscu występowała Maria. Wśród niewolników mężczyzn nie widać takiej dominacji jednego imienia, najczęściej spotykamy imię Juan, Pedro i Diego ${ }^{41}$. Dzieci urodzone przez niewolnice miały imiona bardziej zróżnicowane. Być może w ich nadawaniu liczono się ze zdaniem matek-niewolnic, lecz wśród niewolników urodzonych w Portugalii nie było osób noszących imiona niechrześcijańskie.

Natomiast imiona takie zdarzały się, chociaż sporadycznie, wśród niewolników porwanych lub kupionych w Afryce i przywiezionych do Portugalii. Dwie kobiety, wyzwolona w 1454 r. „Mauryjka” i sprzedana w 1472 r. czarna niewolnica pochodząca z Gwinei, zachowały muzułmańskie imię Fatima $^{42}$. Podobnie dwóch mężczyzn. Byli to: wyzwolony w 1471 r. Homar (Omar), pochodzący z Gwinei i będący w posiadaniu właścicieli „od dawna" (muito tempo), oraz wyzwolony w 1493 r. stary, sześćdziesięcioletni niewolnik Mahomet ${ }^{43}$. Można przyjąć, że praktyka pozostawiania imienia muzułmańskiego istniała, ale była rzadka. Ponadto niewolnik mógł odmówić przyjęcia chrztu, chociaż przekreślał w ten sposób szanse na swoje wyzwolenie. Dlatego imiona muzułmańskie poświadczone są sporadycznie także w końcu stulecia XV.W dokumentach królewskich dotyczących kupna ubrań dla niewolników występuje w 1493 r. pewien Mafamede jedyny wśród dwunastu wymienionych niewolników noszących poza nim imiona chrześcijańskie ${ }^{44}$.

W dokumencie z $1495 \mathrm{r}$. wymieniony został czarny niewolnik pochodzący z Gwinei o imieniu Bukar. Natomiast w 1502 r. sprzedany został Amar, z pochodzenia Wolof ${ }^{45}$. Miał około 30 lat. $Z$ kolei w roku 1500, wedle protokołów notarialnych z ksiąg miejskich Sewilli, czarny dziesięcioletni chłopiec o imieniu Muça przekazany został przez właściciela do warsztatu jubilerskiego dla nauki zawodu ${ }^{46}$. Ponieważ to imiona mu-

${ }^{41}$ W tomach 1-3 PMA opublikowane zostało 89 aktów dotyczących głównie sprzedaży i wyzwolenia niewolników zawierających ich imiona, w tym 42 dotyczy kobiet i dziewczynek. Wśród nich 15 nosiło imię Catalina. Wśród 47 dokumentów dotyczących mężczyzn i chłopców imię Juan nosiło 9 osób, Pedro i Diego po 5.

${ }^{42}$ PMA, $1 / 72 ; 2 / 122$.

${ }^{43}$ PMA, 1/70; $2 / 61$.

${ }^{44}$ PMA, 2/57. Przypadki odmowy chrztu sygnalizuje już Zurara, patrz: Zurara-Soares, s. 549; Zurara-Bourdon, s. 265.

${ }^{45}$ PMA, 2/116; 3/175.

${ }^{46}$ PMA, 2/262. 
zułmańskie, być może są to właśnie dowody odmowy przyjęcia chrztu przez niewolników.

Zdarzały się również przypadki zachowania przez czarnych niewolników rodzimych imion niemuzułmańskich. W 1480 r. sprzedana została młoda, około osiemnastoletnia, czarna niewolnica pochodząca z ludu Mandingo, o imieniu Banbana. Zaś w 1489 r. sprzedano czarną, około trzydziestoletnią niewolnicę, pochodzącą z ludu Wolof, o imieniu Penda ${ }^{47}$.

Dokument z 17 marca 1493 r. świadczy, że jeszcze wtedy król Jan (João) II miał niewolników o imionach pogańskich. Przytacza się trzy z nich Tanbo, Tonbe i Baybry ${ }^{48}$. To jednak w tym okresie wypadki wyjątkowe. Decyzja o utrzymaniu imienia niechrześcijańskiego mogła mieć różne przyczyny, poza odmową przyjęcia chrztu przez niewolnika, także interes właściciela. Alfons V, wyzwalając Mauryjkę Fatimę w 1454 r., zobowiązał ją do służby w „Gwinei”. Być może w Afryce imię jej było bardziej użyteczne od chrześcijańskiego.

Powszechna praktyka polegała na nadaniu podczas chrztu imienia chrześcijańskiego i używaniu go przynajmniej oficjalnie. Dokumenty nie pozwalają na ocenę, czy i do jakiego stopnia niewolnicy swoje imiona afrykańskie pamiętali, chcieli je zachować i stosowali w okolicznościach niezależnych od swych właścicieli. W jednym z dokumentów z 1475 r., którymi dysponujemy, niewolnik występuje pod dwoma imionami Pedro-Muça, a więc chrześcijańskim i muzułmańskim ${ }^{49}$. Jest to przypadek tłumacza wypożyczonego do pracy w Gwinei, co przywodzi na myśl decyzję Alfonsa V.

W większości przypadków chrzest i nadane niewolnikowi imię przenosiły go do portugalskiego społeczeństwa chrześcijańskiego. W życiu niewolnika dokonywała się symboliczna i rzeczywista zmiana. Wywierała ona bez wątpienia wpływ na jego psychikę, choć nie znamy stopnia zmiany samoidentyfikacji, zapewne w poszczególnych wypadkach różnej. Chrzest i imię powodowały też zmianę postrzegania niewolnika z zewnątrz. Stawał się on członkiem wspólnoty, choć oczywiście o najniższej randze społecznej.

Poza chrztem i zmianą imienia ważnym środkiem adaptacji niewolnika do społeczności portugalskiej stawał się ubiór. Niewolnicy pochodzili $z$ różnych rejonów Afryki. Tam, gdzie docierały wpływy islamu, a zarazem rozwinięta była uprawa bawełny, okrycie ciała szatami lub przynaj-

\footnotetext{
${ }^{47}$ PMA, $1 / 119 ; 2 / 4$.

48 PMA, $2 / 57$.

${ }^{49}$ PMA, $1 / 95$.
} 
mniej przepaską z tkaniny było powszechne ${ }^{50}$. Nagość dominowała natomiast tam, gdzie bawełny nie uprawiano, w strefie lasu tropikalnego, na wybrzeżu Gwinei od Sierra Leone do Beninu. Tylko wąskie elity mogły tam nosić importowane stroje z bawełny. Stroje i przepaski wytwarzano z liści i włókien roślinnych.

W czasie pierwszych wypraw portugalskich do Afryki nagość była przez odkrywców dostrzegana i krytycznie, bardzo emocjonalnie ocenia$n a^{51}$. Uważano ją za przejaw niższości cywilizacyjnej Afrykanów, stanowiła element przypisywanego im „bestialstwa”. Bez względu na ubiór niewolników lub jego brak kupcy dążyli do maksymalizacji zysku. Nawet jeśli pozostawiano niewolnikom skromne przepaski, powstawał problem ich ubrania w Portugalii. Nago nie mogliby funkcjonować w społeczeństwie.

Obowiązek ubrania niewolników spadał na ich właścicieli od momentu zakupu. Informuje o tym już Zurara po cytowanym wcześniej fragmencie o wydarzeniach w Lagos. Niewolnikom, po ich podziale, przygotowano jedzenie i „okryto ubraniami ich ciała”. Kronikarz pisze też, że niewolni lubowali się w jaskrawych kolorach szat, a niektórzy zbierali kawałki tkanin, które odpadły z szat Portugalczyków, naszywali te różnokolorowe strzępy na swoje okrycia i znajdowali w tym wiele przyjemności ${ }^{52}$. Tak więc bardzo wcześnie pojawiło się dążenie niewolników do dostosowania ubrań do własnego poczucia estetyki.

Zwyczaj i obowiązek ubierania niewolników przez kupujących potwierdza opis podróży do Portugalii śląskiego rycerza Mikołaja von Popplau. Jego wyprawa w służbie cesarza Fryderyka III miała między innymi cele wywiadowcze. W Portugalii przebywał w sierpniu i wrześniu 1484 r., do czego jeszcze powrócimy. Śląski rycerz otrzymał od króla dwóch cennych niewolników. Wysłannicy władcy dali mu ich do wyboru spośród 50, którzy „mniej więcej przed ośmiu dniami przywiezieni zostali na statkach". Kupiono ich w Lizbonie w imieniu króla na oczach von Popplaua. „Owych ubrałem niezwłocznie - zanotował podróżnik - ponieważ byli całkiem nadzy, tak jak ich Bóg stworzył"53.

${ }^{50}$ Ch. Monteil, Le coton chez les Noirs, „Bulletin du Comité Scientifique et Historique de l'AOF" 1926, 4, s. 585-684.

${ }^{51}$ A. Chabrowska, ,Afrykanie w oczach Europejczyków w dobie wczesnej ekspansji kolonialnej. Afryka Zachodnia do końca XV w.", Warszawa 2008, s. 21-28, mps pracy mgr. w archiwum Wydziału Historycznego Uniwersytetu Warszawskiego.

${ }^{52}$ Zurara-Soares, s. 151-152; Zurara-Bourdon, s.112.

${ }^{53}$ Reisebeschreibung Niclas von Popplau, Ritters, bürtig von Breslau, wyd. P. Radzikowski, Kraków 1998, s. 83; „[die besten zewy Mohren] die ohn gefehr vor acht Tagen in Schiffen zugeführet waren [- - ]. Die selben kleidet ich allso bald, denn sie waren ganz nacket wie sie Gott geschaffen hatte"; Opisanie podróży Mikołaja von Popplau rycerza rodem z Wrocławia, red., tłum. idem, Kraków 1996, s. 78. 
O ubieraniu niewolników przez właścicieli świadczą także dokumenty. Pięć z nich zawartych w zbiorze PMA to polecenia królewskie Jana II z 1493 r dla zarządcy o imieniu Rui Gil, aby przygotował odpowiednie ubrania dla wskazanych z imienia niewolników pracujących w stajniach królewskich ${ }^{54}$. Król wymienił dokładnie typy okryć: koszule, spodnie, nakrycia głowy, rodzaje płaszczy, z różnych tkanin, w tym importowanych z Bristolu, Ypres i z Francji. Były to więc stroje kosztowne, chodziło bowiem o niewolników królewskich i o reprezentację władcy. Jedno z tych poleceń dotyczy trzech niewolników dopiero przywiezionych przez pewnego Pedro z Konga. Natomiast z 1510 r. pochodzi notatka przesłana przez nieznaną skądinąd Marię Pires do niezidentyfikowanego sekretarza, w której poleca ona przygotowanie z tkanin bawełnianych i lnianych strojów potrzebnych, „by ubrać czarnych” ( para vestir os negros) ${ }^{55}$. Z kolei w 1475 r. właściciel wypożyczający niewolnika tłumacza, poza wynagrodzeniem dla siebie, postawił warunek, że jeśli handel przyniesie dobre rezultaty, to ów tłumacz dostanie 50 maravedi na ubranie (a su vestuario) ${ }^{56}$.

Dokumenty tego typu są rzadkie, wystawiane były zazwyczaj przez osoby posiadające wielu niewolników i korzystające w tym przypadku z pośrednictwa urzędników. Jeśli nabywca kupił jednego lub kilku ludzi, kupował też dla nich ubrania bez potrzeby wystawiania w tej drugiej sprawie dokumentów.

Ubieranie niewolników było tyleż spontaniczną, co ważną metodą włączania tych ludzi do portugalskiej społeczności. Akulturacja zachodziła w tym przypadku stosunkowo szybko i skutecznie, gdyż odzienie nie budziło oporu niewolników, było raczej przyjmowane z chęcią.

W formularzu opisywania niewolników w chwili sprzedaży lub wyzwolenia znajdowały się elementy utrwalające ich poczucie odrębności i ich związek z kulturą afrykańską, z której zostali wyrwani. Pełniły więc rolę sprzeczną z zamierzoną akulturacją.Zastanawiające jest umieszczanie w dokumentach informacji o miejscu pochodzenia niewolnicy/niewolnika w Afryce lub o przynależności plemiennej. Używano określenia natural de..., czyli „pochodzący z..." lub „urodzony w...”. Łączono tę informację $\mathrm{z}$ kolorem skóry (escrava negra, escravo negro). Informacja o pochodzeniu umieszczana była w zdecydowanej większości przypadków w dokumen-

${ }^{54}$ PMA, 2/57, 63, 66, 68, 80.

${ }^{55}$ PMA, 5/197.

${ }^{56}$ PMA, 1/95. Maravedi to w drugiej połowie XV i w XVI w. drobna, miedziana moneta hiszpańska. Według: F. Braudel, Morze Śródziemne i świat śródziemnomorski w epoce Filipa II, t. 1, Gdańsk 1976, (oryg. franc. 1966), s. 456-457, przyp. 332, w XVI w. liczono 350 maravedi na złoty dukat obrachunkowy i 400 maravedi na złoty, realny escudo. 
tach dotyczących pojedynczych niewolników ${ }^{57}$. W zbiorczych spisach dużych transportów ludzi znajdowały się osobne rubryki: pochodzenie (origem) oraz skóra (cor) ${ }^{58}$.

Wskazywano albo kraj, region pochodzenia niewolnika, albo jego przynależność plemienną - przy czym nie rozróżniano tych typów identyfikacji. Skrupulatne podawanie tych informacji dowodzi, że służyły one najwidoczniej do klasyfikacji niewolników. Być może niektórym miejscom pochodzenia przypisywano lepszą jakość towaru. Jednakże nie wiemy, w jaki sposób właściciele posługiwali się tą wskazówką. Nie znali przecież języków różnych ludów Afryki, aby przy ich pomocy identyfikować pochodzenie swych niewolników. Może opierali się na oświadczeniach kupców przywożących ludzki towar z Afryki oraz na informacjach pochodzących od samych niewolników. Jest prawdopodobne, że rozpoznawano różne cechy zewnętrzne niewolników i wiązano je z miejscem pochodzenia w Afryce. W każdym razie określenie tego miejsca (lub przynależności etnicznej) musiało być użyteczne, skoro powszechnie je odnotowywano.

Jeśli pamięć o pochodzeniu niewolnika była przechowywana i przypominana przez pierwszego właściciela lub kolejnego nabywcę, to tym bardziej trwała ona w świadomości Afrykanów żyjących w niewoli. Stanowiła element ich samoidentyfikacji. Umożliwiała im porozumiewanie się z innymi niewolnikami tegoż pochodzenia, a nawet przechowywanie niektórych elementów własnej, afrykańskiej kultury, takich - poza językiem - jak tańce, śpiew, muzyka, rodzaje gestó $w^{59}$. Oczywiście w drugim pokoleniu, urodzonym już w Portugalii, identyfikacja przez pochodzenie z Afryki zanikała. Mogła jednak trwać w kulturze przejmowanej przez dzieci od matek, a umacnianej przez ciągłe przywożenie do Portugalii następnych niewolników pochodzących z tego samego regionu Afryki.

Część niewolników afrykańskich była biała. Ludzie ci pochodzili z Wysp Kanaryjskich oraz z saharyjskiego wybrzeża Afryki Zachodniej, zasiedlonego przez berberskich Azenegów. O porywaniu Kanaryjczyków

${ }^{57}$ Dla przykładu PMA, 1/11, dokument Alfonsa V z 17 maja 1454 r.: „Fatima moura natural de terra d'Arzique”; $1 / 70$, dokument tegoż władcy z 18 grudnia 1471 r.: „huum escravo de Guinee per nome chamado Homar"; 2/45, dokument z 3 kwietnia 1492 r.: „esclavo de color negro, que a por nombre Juan, natural de Xolofo".

${ }^{58}$ Dla przykładu spis niewolników sprzedawanych w Sewilli w styczniu, lutym i marcu 1496 r.: PMA, 2/158, zawiera rubryki: liczba niewolników, płeć, skóra, wiek, pochodzenie, sprzedający, kupujący, cena, opłata. O silnych związkach handlowych Portugalii z Sewillą i o podobieństwie tamtejszej sytuacji niewolników patrz niżej, tekst i przypisy 73 i 107. Patrz także: R. Pike, Sevillian Society in the Sixteenth Century: Slaves and Freedmen, „The Hispanic American Historical Review” 47, 1967, 3, s. 344-359.

${ }^{59}$ A.C. Saunders, op. cit., s. 89. 
i Azenegów informował obficie Zurara ${ }^{60}$. W dokumentach zawartych w PMA (protokołach notarialnych z Sewilli) nie wymienia się Azenegów, a Kanaryjczyków kilkakrotnie ${ }^{61}$.Zdecydowaną przewagę liczebną mają jednak wzmianki o niewolnikach czarnych. Ich najczęściej wymieniane pochodzenie dotyczy dosyć ogólnie Gwinei, czyli wybrzeża Afryki Czarnej na południe od ujścia Senegalu. Występują jednak, i to stosunkowo licznie, informacje szczegółowe. Na drugim miejscu pod względem liczebności po Gwinei wymienia się kraj i lud Wolofów ${ }^{62}$. Stosunkowo liczne są informacje o niewolnikach pochodzących z Çapa czy Zapa (zapewne Sapi lub Sapes z terenu Sierra Leone). Mniej liczne są wzmianki o Mandingach ${ }^{63}$. Pojedyncza informacja dotyczy niewolników z Beninu. Jeden raz wymieniona jest Mina ${ }^{64}$. Rzadkość tego przypadku nie dziwi, bo do końca XV w. do Miny niewolników przywożono z Beninu, a nie wywożono ich do Portugalii. Pojedynczo wymienione są też nazwy Alem, Gogoli, Cap de Guer, Tymes część z nich wydaje się trudna do zidentyfikowania ${ }^{65}$.

Wszystkie te określenia miały znaczenie dla osób sporządzających dokumenty, były przez nie rozumiane i odnoszone do geograficznej i etnicznej sytuacji w Afryce. Nazwy te krążyły w Portugalii oraz trafiały do Sewilli wraz ze sprzedawanymi tam niewolnikami. Używane były w procedurze prawnej identyfikowania lub oceniania wartości niewolników, ale jednocześnie odgrywały rolę nośnika informacji nie tylko o tych niewolnikach, lecz i o samej Afryce. Tworzyły w powszechnej wyobraźni obraz Afryki i jej regionalnych podziałów. To właśnie ze względu na handel niewolnikami i sposób identyfikowania niewolników wiadomości te docierały do znacznie większej (niż sami odkrywcy i kupcy) liczby ludzi pochodzących z różnych grup społecznych. Stanowiły one jeden z wielu nośników wiedzy o Afryce, przy tym praktyczny i łatwo przyswajalny.

${ }^{60}$ Zurara-Soares, s. 93-94, 110, 121, 133-134, 139-140; Zurara-Bourdon, s. 84-85, 94, 99, 102-104, 107.

${ }^{61}$ PMA, $1 / 73-1472 ; 2 / 158-1496 ; 3 / 185-1503$.

${ }^{62}$ PMA, $1 / 122-1480 ; 2 / 4-1489,45-1492,53-1492,54-1492,65-1493,69-$ $1493,109-1495,124-1495,224-1498 ; 3 / 107-1501,171-1502,175-1502,211-$ 1503. Są to protokoły notarialne z Sewilli. Terytorium Wolofów rozciągało się wzdłuż wybrzeża, od ujścia Senegalu do Przylądka Zielonego.

${ }^{63}$ PMA, protokoły notarialne z Sewilli: Çapa, Zapa 3/39 - 1500, $79-1501,87-1501$, 173 - 1502; Mandingo 1/118 - 1480, 119 - 1480, 2/139-1496. Zachodni Mandingowie (Mande) zasiedlali tereny nad średnim i dolnym biegiem Gambii i nad Casamansą.

${ }^{64}$ PMA, Benin (państwo na terenie dzisiejszej południowej Nigerii) 3/74-1501, król Manuel Szczęśliwy wyzwala niewolnika Lourenço pochodzącego z Beninu; Mina (nazwa fortu portugalskiego i wybrzeża zwanego Złotym na terenie obecnej Ghany) 2/239 _ 1499, król Manuel Szczęśliwy wyzwala niewolnicę Beatriz za zasługi w służbie w Mina.

${ }^{65}$ PMA, protokoły notarialne z Sewilli: 2/61 - 1493, $122-1495$; 3/57 - 1501, $142-1502,201-1503$. 
Afryka w jej różnorodności regionalnej i etnicznej stawała się obecna w świadomości i potocznym życiu zwykłych Portugalczyków oraz silnie z Portugalią związanych mieszkańców Sewilli.

Działo się tak tym bardziej, że typowym zatrudnieniem niewolników obu płci była służba domowa ${ }^{66}$. Miało to duży wpływ na interesujący nas $\mathrm{w}$ tej pracy kontakt kulturowy. Niewolnica lub niewolnik służący w domu właściciela znali dobrze jego osobę i rodzinę, tryb życia i obyczaje. Często przyjmowali nazwisko właściciela ${ }^{67}$. Podobnie właściciel znał dobrze swego służącego, jego sposób postępowania, obyczaje. W kontaktach tak bardzo osobistych, chociaż naznaczonych i obciążonych zależnością niewolniczą, istniała z obu stron cała gama postaw, uczuć i metod postępowania. Możemy je sobie wyobrazić, ale źródłowo przebadać tylko w niewielkiej części. W każdym razie obustronna znajomość nie ulega wątpliwości.

Podobnie działo się w przypadkach innych znanych nam zajęć niewolników. Jeśli służyli oni na karawelach portugalskich płynących do Afryki, na przykład jako tłumacze, to również nawiązywali z członkami załogi bardzo bliskie kontakty ${ }^{68}$. Mogli też być zwykłymi członkami załóg, chociaż w tym przypadku zatrudniano raczej wyzwoleńców niż niewolników. Bliski kontakt z portugalskim otoczeniem mieli także młodzi niewolnicy, oddani przez swoich właścicieli na naukę zawodu do warsztatów rzemieślniczych lub też zatrudniani jako uliczni drobni przekupnie lub roznosiciele i sprzedawcy wody ${ }^{69}$. Natomiast zatrudnienie grup niewolników liczących kilkadziesiąt osób w zakładach takich jak młyny, piece i kuźnie, gdzie nie mieli oni intensywnych kontaktów z otoczeniem, należało do rzadkości ${ }^{70}$.

Niewątpliwa bliskość życia większości właścicieli i ich niewolników ułatwiała przekazywanie sobie wzajemnie informacji. Nie działo się to w sposób usystematyzowany i przemyślany ( jak to miało miejsce na dworze infanta Henryka), ale raczej w sposób spontaniczny i jako uboczny skutek ciągłego obcowania. Trzeba jednak pamiętać, że kontakt ten miał specyficzny charakter - łączył pana i niewolnika, czyli nierówne strony. Niewolnik żył w ciągłym zagrożeniu zmianą sytuacji, w tym sprzedaniem innemu właścicielowi.

${ }^{66}$ Ch. Verlinden, op. cit., s. 632; A.C. Saunders, op. cit., s. 66-69.

${ }^{67}$ PMA, 3/64 - 1501, Elvira Rodriguez i jej niewolnica Juana Rodriguez.

${ }^{68}$ M. Tymowski, How did, s. 49-50, 52-55.

${ }^{69}$ A.C. Saunders, op. cit., s. 76-77.

${ }^{70}$ PMA, 2/177 - 1497; 3/92 - 1501. Oba dokumenty są rozliczeniami wydatków na niewolników pracujących w młynach królewskich, zatwierdzonymi przez króla Manuela Szczęśliwego. 
Przytoczony na początku artykułu fragment kroniki Zurary świadczy o wzbudzeniu litości i o proteście ludzi w sytuacji, gdy niewolników dzielono. Spontanicznie odebrano to jako czyn bardzo okrutny. Ale w miarę rozwoju handlu niewolnikami serca twardniały. Spontaniczna - i w naszych oczach chwalebna reakcja ludu Lagos już się nie powtórzyła. Badanie okrucieństwa w stosunkach międzyludzkich przysparza licznych problemów ${ }^{71}$. Czy możemy stosować tu nasze współczesne miary i odczucia? Czy też musimy opisać i przeanalizować system wartości i ocen istniejący w przeszłości, a więc szukać miar okrucieństwa właściwych społeczeństwu, które badamy? Społeczeństwu, w którym handel niewolnikami stał się zjawiskiem codziennym, nieodbieranym już jako okrutne. Traktowano tak natomiast wyjątkowe i bezcelowe nadużycia, o czym świadczy skazanie w 1511 r. Gonçalo Roiza, kapitana statku niewolniczego, który żywcem wrzucał do morza dorosłych niewolników i dzieci ${ }^{72}$.

W trakcie masowego przewozu dużych grup niewolników z Afryki do Portugalii doszło do wykształcenia się terminu peças - „sztuki”, w których liczono ludzi. W spisach transportowanych niewolników już na początku XVI w. peça oznaczała jednego dorosłego człowieka, jak też kobietę z maleńkim dzieckiem. I tak w spisie niewolników wiezionych w $1506 \mathrm{r}$. z Arguim 6 kobiet z małymi dziećmi określono jako 6 sztuk $^{73}$. Zwyczaj ten upowszechnił się w trakcie XVI w. i stał się przejawem odczłowieczenia ludzkiego towaru. Nierozłączanie niewolnicy i jej niemowlęcia miało ponadto sens praktyczny, gdyż stwarzało dziecku możliwość przeżycia, choć na pewien czas ograniczało wydajność pracy kobiety.

Sprzedawano zarówno niewolników właśnie przywiezionych z Afryki, jak i tych, którzy byli już czyjąś własnością w Portugalii. Pewną część niewolników wywożono do Kastylii. Eksport ten nie budził zastrzeżeń, był tylko obciążony opłatami celnymi ${ }^{74}$.

Natomiast sprzedaż niewolników cudzoziemcom pochodzącym z państw bardziej odległych budziła w XV w. wątpliwości i sprzeciwy. Podróżnik Lew z Rožmitalu w 1466 r. miał otrzymać od króla Alfonsa V dwóch Murzynów, ale Ferdynand książę Viseu skutecznie temu zapobiegł,

${ }^{71}$ J. Tazbir, Okrucieństwo w nowożytnej Europie, Warszawa 1993, s. 7-26.

${ }^{72}$ Monumenta Missionaria Africana, t. 1: Africa Ocidental (1471-1531), wyd. A. Bràsio, Lisboa 1952, s. 215-221.

${ }^{73}$ PMA, ,sztuki” w portugalskich spisach niewolników przewożonych statkami: 3/260 - 1504, 262 - 1505, 263 - 1505. Matki z niemowlętami jako „sztuki” w spisie 5/46 z 1506 r. ,item seis molheres [- - ] com suas cryanças [- - 6 peças...”.

${ }^{74}$ W PMA zostały opublikowane liczne wpisy notarialne pochodzące z ksiąg miejskich Sewilli. Decyzja wydawców PMA, aby w monumentach portugalskich umieścić te materiały, oraz treść tych wpisów uwypuklają podobieństwo sytuacji niewolników w Portugalii i w Sewilli. Patrz też dalej tekst i przyp. 109. 
argumentując, że niewolnicy byli już ochrzczeni i przekazywać ich nie można. Zapewne przyczyna wstrzymania daru była inna, ochrzczonych niewolników sprzedawano przecież bez ograniczeń. Obawiano się raczej gromadzenia przez przybyszów wiadomości wywiadowczych. Wedle jednych informatorów Lew otrzymał w zamian dwa rumaki, wedle innych dwóch białych niewolników „Maurów”75.

Podobnie wspomniany już śląski rycerz Mikołaj von Popplau miał być obdarowany w 1484 r. przez króla Jana II „dwiema żywymi Murzynkami", lecz z nieznanych powodów ich nie otrzymał. Podarowano mu natomiast dwóch kupionych na targu niewolników. Śląski rycerz zanotował, że „kraj Maurów Gwinea [- - ] przynosi rocznie do Portugalii [- - ] bardzo wiele złota i wziętych do niewoli Murzynów". Gdy Popplau wyjechał do Kastylii, owi dwaj niewolnicy zostali ocleni, czemu rycerz się sprzeciwiał bez skutku ${ }^{76}$. Ponieważ więcej o nich w swym opisie nie wspominał, zapewne sprzedał ich w Sewilli.

Los tych dwóch niewolników, przywiezionych właśnie z Afryki, sprzedanych w Portugalii wysłannikom króla, podarowanych obcokrajowcowi, przewiezionych do Kastylii i tam znowu sprzedanych, ukazuje niepewność i zmienność ich losu. Dotyczyło to szczególnie niewolników świeżo z Afryki sprowadzonych.

Sprzedawani byli także ci, którzy od dłuższego czasu pozostawali czyjąś własnością. Wśród licznych aktów sprzedaży szczególną uwage przyciągają dokumenty poświadczające sprzedaż dzieci. Sposób przeprowadzania tych transakcji i ich okoliczności mogą być wskazówką dotyczącą typu kontaktów między właścicielami i ich niewolnikami. Zgodnie ze średniowiecznymi zasadami przyjmujemy wiek 12 lat za granicę przejścia z dzieciństwa do świata dorosłych, na przykład możliwości zawierania małżeństw. Trzeba jeszcze przypomnieć o metodzie ustalania wieku niewolnika. Tylko urodzeni w Portugalii i ochrzczeni mieli wiek ustalony. W stosunku do innych pisano „około”, „mniej więcej”77.

W dokumentach nas interesujących ze zbioru PMA znajdujemy szesnaście aktów notarialnych z Sewilli dotyczących sprzedaży dzieci lub przekazywania ich za długi ${ }^{78}$. Jest to oczywiście wybór dokumen-

${ }^{75}$ Cytuję za Reisebeschreibung, s. 74, n. 311; Opisanie podróży, s. 69, przyp. 232.

${ }^{76}$ Reisebeschreibung, s. 74 „zwey lebendige Möhrin”, s. 78 „Man nennet sonsten der Mohren Landt Ginea. Bringt jährlich sehr viel Goldes und gefangener Mohren aus dem Lande in Portugall”, oclenie - s. 90, 93; Opisanie podróży, s. 69, 73, 78, 87.

${ }_{77} \mathrm{Na}$ przykład PMA, 1/142 - 1483 ,de hedad de quarenta años, poco mas o menos”.

${ }^{78}$ PMA, 2/5 - 1489, $6-1489,52-1492,54-1494,70-1493,104-1495,121-$ 1495 ; $3 / 17-1500,48-1501,139-1502,152-1502,172-1502,202-1503,224-$ $1504,249-1505 ; 5 / 29-1505$. 
tów, lecz wydaje się reprezentatywny dla tego zjawiska. Owych siedemnaście dokumentów pochodzi z lat 1489-1506. Dzieci, jak świadczy cytowany fragment kroniki Zurary, przywożono od początku porywania ludzi w Afryce. Brak dokumentów sprzed 1489 r. nie znaczy więc, że proceder przed tą datą nie istniał.

W analizowanych dokumentach wiek dzieci rozpięty jest miedzy 15 dniami a 11 latami. Sprzedawane dzieci miały najczęściej od 5 do 10 lat, czyli mogły już żyć bez matek. Akty sprzedaży pojedynczych niewolnic z dziećmi nie zdają się świadczyć o względach humanitarnych ani o litości nad tymi ludźmi. Chodziło raczej o przeżycie dzieci. Dysponujemy dokumentami sprzedaży kobiet z dziećmi, które miały rok, półtora roku i dwa lata ${ }^{79}$.

Dziesięć dokumentów dotyczy sprzedaży samych dzieci, bez matek. Były to albo dzieci przywiezione z Afryki już bez matek, albo dzieci zrodzone w Portugalii lub w Sewilli z matek-niewolnic. Z punktu widzenia losu i dramatu tych dzieci obie sytuacje były tragiczne i podobne. Natomiast z punktu widzenia stosunku właścicieli do swoich niewolników istniała różnica. Już w roku 1489 w księgach miejskich Sewilli znajdujemy wiadomość o sprzedaniu czarnej, około siedmioletniej niewolnicy Marii, pochodzącej z Jahen. Z tej samej miejscowości pochodził z resztą jej nabywca $^{80}$. Była to więc niewolnica urodzona w Europie i wszystko wskazuje na to, że oderwano ją od matki. Tym bardziej było tak z piętnastodniowym niemowlęciem sprzedanym w Sewilli w 1492 r. za niską cenę 10 reali w srebrze ${ }^{81}$.

Większość aktów sprzedaży dzieci dotyczy osób kilkuletnich, już przez matki odchowanych, i ma wyraźny cel zarobkowy. Część z tych dzieci urodziła się w Portugalii (lub w Kastylii). O dziewięcioletniej Magdalenie, sprzedanej w 1500 r. w Sewilli, napisano ,urodzona w tymże wymienionym mieście" ${ }^{82}$. W jednym wypadku dokument mówi wprost o oderwaniu dziecka od matki. Oto w 1502 r. w Sewilli właściciel sprzedał Catalinę, czarną, około trzydziestoletnią niewolnicę pochodzącą z Gwinei, oraz pięcioletnią Marię, córkę swojej innej niewolnicy Franciszki ${ }^{33}$. Sprzedawano też dzieci urodzone w Afryce i tam oddzielone od matek. W 1492 r. sprze-

${ }^{79}$ PMA, 3/152, 224; 5/29.

80 PMA, $2 / 6$.

${ }^{81}$ PMA, 2/52. Dziesięć reali w srebrze to około 340 maravedi, czyli poniżej 1 dukata. Przy cenie dorosłego niewolnika (także „sztuki” złożonej z matki z niemowlęciem) około 10 dukatów, byłoby to mniej niż 10\% takiej ceny. Jednak wyjątkowo cenni niewolnicy mogli kosztować nawet 30 dukatów.

82 PMA, 3/17: „nascita en esta dicha cibidad”. Dla porównania sprzedana wtedy dziewięcioletnia Magdalena kosztowała nabywcę 7200 maravedi.

${ }^{83}$ PMA, 3/139. 
dano siedmioletniego chłopca o imieniu Godin, urodzonego w kraju Wolofów. Pięcioletnia Ysabel, urodzona w Gwinei esclavita, oddana została za dług, którego jej właściciel nie mógł spłacic ${ }^{84}$.

W świetle tego materiału nie wydaje się, aby właściciele mieli zahamowania lub wyrzuty sumienia w przypadku sprzedawania dzieci oderwanych od matek. Przy sprzedaży matek z niemowlętami decydowały względy praktyczne. Natomiast przy sprzedaży już dzieci odchowanych, względy ekonomiczne. Zastanawiający i jednostkowy przypadek sprzedaży bez matki piętnastodniowego niemowlęcia nie był spowodowany chęcią zysku, gdyż właściciel otrzymał sumę niewielką. Być może matka dziecka zmarła przy porodzie lub był to rodzaj kary wymierzonej niewolnicy - do czego jeszcze powrócimy.

Musimy przy tym pamiętać o typie i ograniczeniach materiału źródłowego, którym dysponujemy. Po pierwsze, wśród licznie sprzedawanych młodych niewolnic mogły być kobiety, od których oddzielono dzieci. Dokumenty tego nie odnotowywały. Po drugie, nie znamy liczby przypadków, gdy właściciel nie sprzedawał ani kobiety, ani jej dziecka i oboje zachowywał dla siebie.

Pewną wskazówką mogą być rejestry majątków po zmarłych lub zbankrutowanych właścicielach. I tak w 1489 r. zmarły Pedro Mexia pozostawił między innymi trzydziestoletnią czarną niewolnicę Ynes i jej sześcioletniego syna, o jasnym kolorze skóry (de color loro). Natomiast w dobrach Luisa de la Mezquita przejętych w 1495 r. znajdowała się dwudziestopięcioletnia czarna niewolnica Pendra i jej dwóch synów po około 4 lata każdy ${ }^{85}$. Obaj ci właściciele nie sprzedali matek-niewolnic ani osobno, ani z dziećmi. Ale w obu przypadkach śmierć lub upadłość właściciela mogły oznaczać dla kobiet i ich dzieci ryzyko rozdzielenia. W pierwszym z opisanych przypadków jest możliwe, że ojcem chłopca - mulata był właściciel niewolnicy.

Przypadki dzieci czarnych niewolnic o jaśniejszym kolorze skóry odnotowano w naszych dokumentach kilkakrotnie. W 1489 r. w Sewilli sprzedano szesnastoletniego niewolnika o imieniu Rodrygo, jasnego koloru skóry (de color loro), syna Cataliny, czarnej niewolnicy należącej do sprzedawcy ${ }^{86}$. Czarne niewolnice mogły utrzymywać stosunki z białymi właścicielami pod mniej lub bardziej dojmującą presją, do gwałtu włącznie. Były niewolnicami, ale i chrześcijankami i teoretycznie czyn taki był zabroniony, ale w praktyce zazwyczaj pozostawał bezkarny. Zdarza-

\footnotetext{
${ }^{84}$ PMA, 2/54, 70. Podobne informacje 2/70,121;3/48, 202.

${ }^{85}$ PMA, 2/5, 104.

${ }^{86} \mathrm{PMA}, 2 / 7$.
} 
ły się jednakże wyjątki. W 1490 r. król Jan II ułaskawił rycerza Alvaro de Vila Franca, mieszkańca Setubal, ożenionego z Violante Afonso. Rycerza oskarżono o to, że miał córkę z jedną ze swych niewolnic, czarną chrześcijanką pochodzącą z Gwinei. Córkę za zgodą żony przyjął do swojego domu. Żona wiedziała więc o grzechu, a oskarżony prosił o łaskę, którą od króla otrzymał pod warunkiem, że do tego grzechu nie powróci ${ }^{87}$. Można przypuszczać, że oskarżenie było formą nacisku ze strony małżonki i że bez jej starań sprawa nie byłaby rozpatrywana. Pozostaje jednak faktem, że czyn rycerza był karalny, a niewolnice były w minimalnym przynajmniej stopniu chronione. Zgoda żony na przyjęcie do domu dziecka narodzonego z takiego stosunku uzmysławia nam, że zgody mogło nie być. Właśnie w takim wypadku mogło dojść do sprzedaży niemowlęcia. Również mężczyzna mógł sam podjąć taką decyzję.

Tak oto - poprzez okrycie ubraniem, chrzest, nadanie imienia, naukę języka oraz zasad pracy - odbywało się stopniowe włączanie ludzi przywiezionych z Afryki w społeczeństwo portugalskie. Potem pojawiały się dzieci niewolnic. Dziedziczyły one status niewolniczy, ale odnotowywano ich pochodzenie z miast Portugalii, ewentualnie Kastylii. Dzieci urodzone w Portugalii znały język lepiej niż ich matki. Nie był to jednak język poprawny, lecz jego wersja uproszczona i zniekształcona, zwana fala de Guiné lub fala dos pretos i fala dos negros - mowa gwinejska, czarnych, Murzynów. Wedle historyków literatury portugalskiej pierwszy portugalski utwór literacki, w którym autor posłużył się tym językiem, powstał już w 1455 r. W XVI w. utwory takie były liczne, a mistrzowskim opanowaniem tego języka i jego wykorzystaniem w sztukach teatralnych charakteryzowały się sztuki Gila Vicente ${ }^{88}$. W jego utworach komediowych postacie z ludu mówią językiem z ludu, a postacie czarnych niewolników - fala dos pretos. W teatrze użycie tego języka miało aspekt komediowy i odwoływało się do potocznego doświadczenia widzów i słuchaczy. Ale poprzez ironię mogło pełnić funkcję poniżającą i stygmatyzującą grupę społeczną używającą tej mowy. Jest charakterystyczne, że A. Alvares, szesnastowieczny autor komedii i dramatów scenicznych, mulat z pochodzenia, nie posługiwał się nigdy fala de Guinér ${ }^{89}$. Być może byłoby to dla niego zbyt bolesne. Czarnych niewolników mówiących poprawną portugalszczyzną było niewielu. $\mathrm{Na}$ ich określenie używano odrębnego słowa - ladinhos ${ }^{90}$. Podkreślano tym samym wyjątkowość sytuacji. Tak więc obok koloru skóry język należał do

${ }^{87}$ PMA, 2/23.

${ }^{88}$ P. Teyssier, op. cit.; P.E. Russell, Some Socio-Linguistic; A.C. Saunders, op. cit., s. 99-101, 203 nota 66; J. Klave, Historia literatury portugalskiej, Wrocław 1985, s. 120-122.

${ }^{89}$ A.C. Saunders, op. cit., s. 101; J. Klave, op. cit., s. 125.

${ }^{90}$ A.C. Saunders, op. cit., s. 101. 
trwałych czynników wyróżniających osoby niewolne. Były one trwalsze niż prawny status niewolniczy, gdyż ten mógł być zniesiony przez wyzwolenie.

Wyzwolenie następowało w wyniku decyzji właściciela. W niektórych przypadkach należało się ono niewolnikowi zgodnie z prawem. Niewolnik-tłumacz, który w trakcie wypraw do Afryki pozyskał dla swego właściciela czterech niewolników, powinien być wyzwolony. System ten opisał Ca da Mosto przy okazji relacji ze swych podróży w 1455 i 1456 r. Natomiast najstarszy dokument wyzwolenia tłumacza spośród zebranych w PMA pochodzi z 1475 r. ${ }^{91} \mathrm{~W} 1477$ r. wolność odzyskał João Garrido, urodzony w Gwinei czarny niewolnik mieszkańca Lagos, kupca Gonçalo Toscano. Tenże J. Garrido przyjął chrzest i wielokrotnie podróżował jako tłumacz do ziem Gwinei. Mógł wtedy znowu zostać „Maurem” i żyć jak Maur („viiver como mouro”), ale powracał zawsze do swego pana i do Królestwa Portugalii. Był więc - jak głosi dokument dobrym i lojalnym sługą. Z tych względów urzędnik królewski, mocą królewskich praw, w imieniu Jana II, uznał owego niewolnika „uwolnionym i wolnym [- - ] mającym prawo mieszkać i pracować w Królestwie jak każdy inny chrześcijanin portugalski"92.

Zasługi niewolników w czasie wypraw do Afryki były jedną z najważniejszych podstaw ich wyzwalania. W 1499 r. król Manuel Szczęśliwy wyzwolił swoją niewolnicę Beatriz Gomez właśnie za zasługi, które oddała w czasie pobytu w zamku São Jorge da Mina ${ }^{93}$. Natomiast w 1510 r. Manuel de Gois zwrócił się listownie do władcy z prośbą o zatwierdzenie wyzwolenia niewolnika Fernão de Avila, który wysłany był do królestwa Beninu jako tłumacz działający u boku portugalskiego faktora. Tenże Fernão pozostawał w Beninie przez trzy lata i pracował, przysparzając Portugalii wiele korzyści ${ }^{4}$.

Niekiedy władca wyzwalał niewolnika pod warunkiem udania się na służbę w Gwinei. Pierwszy znany nam dokument tego typu pochodzi z 1454 r., jest więc bardzo wczesny. Król Alfons V wyzwolił wtedy wspomnianą już niewolnicę Fatimę, Mauryjkę pochodzącą z Arzique ${ }^{95}$.

${ }^{91}$ Ca da Mosto-Leporace, s. 77-78. Akt wyzwolenia z 1475 r. PMA, 1/95. Patrz też: M. Tymowski, How did, s. 54-55.

92 PMA, 1/101: „[Porem mandamos] que ajam o dicto Johao Garrido por forro e liure vijdo elle a estes Regnos e o leixem em elles morar trautar como qualquer outro cristão portuguees". Tenże dokument w Descobrimentos portugueses, wyd. J. M. da Silva Marques, t. 3, Lisboa 1971, nr 132, s. 173-174.

${ }^{93}$ PMA, 2/239.

${ }^{94}$ PMA, 5/180.

${ }^{95} \mathrm{PMA}, 1 / 11$. 
Często podawanym powodem wyzwolenia była szczera wiara niewolnicy lub niewolnika. Przytaczaliśmy już w innym kontekście przykład Pero Negro, który uciekł do Maroka, lecz potem powrócił, bo czuł się chrześcijaninem. Wyzwolenie tłumacza J. Garrido uzasadnione było tyleż jego zasługami w Gwinei, ile szczerością jego wiary. Król Jan II wyzwolił w 1492 r. niewolnicę Catarinę, przywiezioną z Gwinei przez kupca Marchionniego w wieku 8 lat i sprzedaną żydowskiemu kupcowi z Lizbony o imieniu Guedelha Guoaliter. Po dwóch latach owa Catarina przyjęła chrzest w kościele św. Marii Magdaleny i służyła Marchionniemu jak osoba wolna. Doszło do procesu między dwoma kupcami. Król rozstrzygnął spór, uwalniając ową Catarinę. Uzasadnieniem była jej wiara ${ }^{96}$. Przebieg tego wydarzenia jest dowodem nastrojów i działań antysemickich w Portugalii końca XV w., czyli w okresie wypędzenia Żydów z królestwa (tych, którzy nie przeszli na wiarę chrześcijańską). Chociaż zakaz posiadania niewolników-chrześcijan przez Żydów i muzułmanów istniał już wcześniej, zaczęto go egzekwować dopiero w końcu stulecia ${ }^{97}$.

Wyzwolenia mogły być także wyrazem pobożności właściciela i jego pragnienia dokonania czynu miłego Bogu. W rejestrze notarialnym z Sewilli pod datą 13 lutego 1503 r. odnotowane zostało wyzwolenie przez zakonnika Lope Mexię pewnej Cataliny, czarnej niewolnicy mającej 14 lat, „por memoria de la pasyon de nuestro Señor Jesu Christo" - i jak dodano „e por servicios”. Tenże zakonnik, w tym samym dniu, wyzwolił czternastoletniego Kanaryjczyka Pedro, pod warunkiem jednak, że przez pięć lat będzie służyć niejakiej Teresie Mexii, zapewne z tej samej rodziny co wyzwalający. Było to więc wyzwolenie obwarowane dużym i długim zobowiązaniem.

Osiem dni po tamtych wyzwoleniach, 21 lutego 1503 r., tenże dobroczyńca, określony ściślej jako „frey Lope Mexia, comendador de la orden de Sancti Spiritus", wyzwolił znów czarną, pochodzącą z Gwinei Catalinę, także czternastoletnią, ponieważ owa niewolnica ,jest chrześcijanką i za liczne, dobre i lojalne służby, które świadczyła" 98 .

Inna niewolnica, także Catalina, mająca około 40 lat, została wyzwolona w 1494 r., gdyż wedle właściciela ,służyła mi wiele lat [- - ] i czyniła codziennie liczne, dobre i lojalne usługi [- - ] ku mojemu zadowoleniu i wdzięczności"99. Podobne sformułowania znajdujemy w dokumencie z 1495 r. odnośnie do służby czterdziestoletniej niewolnicy Eleny. W 1497 r.

${ }^{96}$ PMA, 2/46: „es cristiana como por los muytos, buenos y leales servicios que le ha fecho".

${ }^{97}$ A.C. Saunders, op. cit., s. 62-63.

${ }_{98}$ PMA, 3/181, 182, 184.

${ }^{99}$ PMA, 2/100. 
odnotowano wyzwolenie Cataliny, trzydziestoletniej niewolnicy „por servicios e porque es christiana" ${ }^{100}$.

Czasem wzmianki o wiernej służbie mogą przykrywać rzeczywistość bardziej skomplikowaną, nawet okrutną. W 1493 r. wyzwolony został Mahomet, czarny niewolnik mający około 60 lat $^{101}$. Zachowanie przez niego imienia muzułmańskiego, a więc i wiary, w tym wypadku nie przeszkodziło wyzwoleniu. Chwalono go za zasługi. Ale wyzwolenie w tak zaawansowanym wieku przypominało raczej porzucenie. Zdejmowało przecież z właściciela obowiązki i świadczenia należne niewolnikowi.

Tak więc trzy główne powody wyzwolenia podawane w dokumentach to szczera wiara chrześcijańska niewolnicy lub niewolnika, dobra służba i wyjątkowe zasługi. Można oczywiście przyjąć, że wzmianki tego typu wynikały z przyjętego formularza. Lecz ten - jakkolwiek był schematyczny odzwierciedlał przecież intencje wyzwalających. Poza tym w części dokumentów zawarte są obszerne i pełne szczegółów opisy czynów i zasług niewolników. Czwartym powodem, przemilczanym w tekstach, było pozbywanie się starego lub chorego człowieka. Możliwe było wyzwolenie pod warunkiem dalszej służby albo wykupienie się niewolnika. W 1504 r.Pedro Pinelo, kanonik kościoła sewilskiego, przekazał niejakiemu Diegowi Osorio swoje prawa względem niewolnicy Leonor i jej dwóch córek - Luzii i Andrei. Leonor zobowiązała się w swoim i córek imieniu służyć kanonikowi i wypłacić mu sumę 11 tysięcy maravedi, w zamian za wyzwolenie ${ }^{102}$.

Wyjątkowy akt wyzwolenia pochodzi także z Sewilli z 1501 r. Oto Elvira Rodriguez, czarna wolna mieszkanka miasta, wpisała do ksiąg miejskich swój testament. Powierzała swą duszę Bogu i Matce Boskiej i pragnęła być pochowana w kościele św. Jana. Następnie stwierdziła, że uwalnia Juanę Rodriguez, swoją czarną niewolnicę, mającą 20 lat, ,ponieważ jest chrześcijanką i za zasługi, które czyniła". Ten fragment wpisu brzmiący wedle formularza został uzupełniony bardzo osobistym wyznaniem. Elvira uczyniła wyzwoloną Juanę swoją spadkobierczynią „za zasługi, które świadczyła i miłość do niej"103.

W aktach wyzwolenia powtarza się fragment, zapewne wpisywany wedle formularza, dotyczący swobody zamieszkiwania, podróżowania, podejmowania różnych zajęć określający prawa należne wyzwolonemu. Najdobitniej wyraził to cytowany już fragment dokumentu z 1477 r. -

100 PMA, 2/119, 168.

${ }^{101}$ PMA, 2/61. Inne przypadki wyzwolenia jako porzucenia starego lub chorego niewolnika przytacza A.C. Saunders, op. cit., s. 141.

102 PMA, 3/223.

103 „porque es christiana e por servicios que le ha fecho"; ,por servicios que le ha fecho e amor que le tyene", PMA, 3/64. 
wyzwolony mógł żyć w Królestwie „jak każdy inny chrześcijanin portugalski".

W 1490 r. król Jan II wystawił dokument na rzecz Isabel Anes, wdowy po Fernao Rebelo, czarnym mieszkańcu Lizbony. Król udzielał jej przywilejów należnych wdowom po tych, którzy zasłużyli się w Gwinei. W dokumencie użyto określenia „wdowy po naszych wasalach”"104. Ów Rebelo miał więc wszelkie prawa człowieka wolnego, określono go jako wasala królewskiego, pojął za żonę Portugalkę - wszystko to dowodzi jego integracji ze społeczeństwem miejscowym.

O takiej interpretacji świadczą także umowy dotyczące zatrudnienia czarnych wyzwoleńców jako żołnierzy. W 1500 r. czarny Anton Mexia z parafii św. Wawrzyńca w Sewilli służył w charakterze żołnierza z lancą (lanceiro), za wynagrodzeniem 34 maravedi dziennie. W tym samym roku czarny Andrés Mexia, mieszkaniec parafii św. Wincentego w tymże mieście, zawarł umowę na służbę w charakterze kusznika (ballestero), za 35 maravedi dziennie ${ }^{105}$. Natomiast w 1501 r. czarny Juan López, mieszkający w Sewilli w parafii św. Wincentego, i Esteban Marfin, pracownik (lavrador), zaciągnęli wspólnie pożyczkę 970 maravedi u Pedra de Niebli z parafii Santa Maria w Sewilli ${ }^{106}$. Podobne - i zapewne zgodne z formularzem - wpisy określające osoby wolne, bez względu na kolor skóry, zawierały informację o mieście zamieszkania (visinho de...) oraz parafii (en la colacion de...). Te fragmenty dokumentów są świadectwem integracji czarnych wyzwoleńców z miejską społecznością Sewilli.

Innym typem wpisów do ksiąg miejskich były pełnomocnictwa udzielane przez wolne, czarne osoby pochodzenia afrykańskiego wybranym przez siebie przedstawicielom ${ }^{107}$. Powstaje pytanie, czy w Portugalii mieliśmy do czynienia z sytuacją podobną do tej, poświadczanej przez dokumenty z terenu Kastylii, a przede wszystkim z Sewilli. Dowodzić tego może wpis do ksiąg miejskich z 1502 r. Oto Bartolomé de Pinos, cieśla z Sewilli, upoważnił czarnego mieszkańca Lizbony, marynarza João Gonçalvesa, do odebrania wszelkich sum i należności, które portugalscy właściciele i budowniczy statków powinni wypłacić owemu cieśli za jego pracę na statkach pływających do Gwinei ${ }^{108}$.

Dokumenty tu cytowane ukazują rozmaitość spraw i zajęć wolnych, czarnych mieszkańców Sewilli i Lizbony. Mieli oni prawo do występowania przed sądem i urzędami miejskimi, do zaciągania pożyczek, do reprezento-

\footnotetext{
104 „aas veuvas molheres de nossos vasallos”, PMA, 2/20.

105 PMA, 3/8,14.

106 PMA, 3/62.

107 PMA, 3/111 - 1495, $112-1495$.

108 PMA, 3/177.
} 
wania innych osób lub do udzielania i przyjmowania pełnomocnictw. Byli wśród nich marynarze, żołnierze, pracownicy rolni, rzemieślnicy, tłumacze. Pracowali i mieszkali w Sewilli oraz w Lizbonie. Podróżowali jako członkowie załóg karawel do Gwinei. Wszyscy oni byli - co dla ówczesnych stanowiło oczywistość - chrześcijanami. W dokumentach określano ich imieniem, ewentualnie nazwiskiem, kolorem skóry, miastem, w którym osiedli, oraz parafią, do jakiej należeli. W przeciwieństwie natomiast do wpisów dotyczących niewolników ani razu nie uwidoczniono w nich afrykańskiego miejsca pochodzenia. Miejscem pochodzenia wolnych $\mathrm{Mu}-$ rzynów było bowiem miasto, w którym mieszkali i pracowali i którego prawa ich obejmowały.

Sądząc po postępowaniu tych wolnych czarnych Portugalczyków lub Kastylijczyków, którzy udawali się do Gwinei i wracali do Portugalii lub Kastylii, dochodzimy do wniosku, że akceptowali oni swój los. Przyjęli religię, język (czy to w formie fala dos pretos, czy w czystej portugalszczyźnie), obyczaje, nauczyli się różnych umiejętności i zawodów, mogli zawierać małżeństwa. Trzeba jednak pamiętać, że wyzwolenia dotyczyły zdecydowanej mniejszości niewolników. A dokumenty nie pozwalają na zbadanie, czy i jaką część obyczajów i kultury afrykańskiej owi ludzie zachowali. Tym bardziej dotyczy to większości, która do końca życia pozostawała w niewoli. Stopień ich asymilacji i akceptacji przez nich zmiany losu, a przede wszystkim stanu niewoli, był, jak możemy przypuszczać, o wiele mniejszy niż w przypadku wyzwoleńców.

Zasadniczą, obok niewoli, zmianą w życiu Afrykanów przywiezionych do Portugalii było pozbawienie ich rodziny i bliskości krewnych. Afrykanie musieli to odczuwać szczególnie dotkliwie, gdyż ich kultura cechowała się szczególną rolą więzi wielkorodzinnych i rodowych. Ludzie w Afryce żyli w otoczeniu licznych osób sobie bliskich. W Portugalii stawali się samotni. Młode kobiety rodziły wprawdzie dzieci, ale żyły w otoczeniu obcej sobie rodziny właściciela i w ciągłej obawie przed rozdzieleniem z potomstwem. o tym, jakie znaczenie miało dla czarnych Afrykanów poszukiwanie osób sobie bliskich, świadczy wymownie przytoczony testament E. Rodriguez, wyzwalającej swoją niewolnice ,por [- - ] amor que le tyene”.

Tęsknota za ziemią rodzinną i za bliskimi musiała słabnąć w miarę upływu lat i stopniowego godzenia się z losem osoby żyjącej w niewoli. $\mathrm{W}$ większości przypadków asymilacja była nieunikniona. Jednakże wiele do myślenia daje fragment opisu Afryki Północno-Zachodniej autorstwa Valentima Fernandesa. Pisząc o berberskich rybakach z wybrzeża atlantyckiego, Azenegach, ich obyczajach i ubóstwie, o ich porywaniu przez Portugalczyków w latach czterdziestych XV w., Fernandes dodał: „Znałem na przykład pewnego Azenega schwytanego w dzieciństwie i wy- 
chowanego w Portugalii, w której żył jako chrześcijanin 24 lata. Potem uciekł i dotarł do swojej ziemi, gdzie żyje teraz - pozbawiony czegokolwiek, nagi, biedny jak inni, a nawet biedniejszy, bo nie umie nic robić. Żyje z jałmużny, którą dają mu inni [Azenegowie]. A przecież mógłby żyć lepiej, mieć dobre ubranie, ale nie pozwoliła mu na to jego natura" ${ }^{109}$

Charakter kontaktów między kulturami zależy między innymi od liczebności kontaktujących się osób po każdej ze stron oraz od swobody lub przymusu utrzymywania kontaktu. W przypadku niewolników był to wyraźny przymus i brak alternatywy. W dużym stopniu dotyczy to także wyzwoleńców, chociaż mogli oni podjąć decyzję wyjazdu z Portugalii i zerwać w ten sposób istniejące więzy, co jednak nastręczało ogromnych trudności. Kontakt kulturowy był nierównoważny ze względu na fakt, że Afrykanie stanowili około 1\% ludności Portugalii. Ponadto kulturę portugalską cechowała pewna jednolitość, podczas gdy czarni niewolnicy afrykańscy należeli do różnych kultur i grup językowych.

W źródłach portugalskich odzwierciedla się głębokie przekonanie o wyższości kultury chrześcijańskiej i o konieczności ochrzczenia niewolników przywiezionych z Afryki oraz nakłonienia ich do akceptacji europejskiego stylu życia. Zebrany tu materiał świadczy, że cel ten został w znacznym stopniu osiągnięty, przynajmniej jeśli chodzi o zewnętrzne przejawy asymilacji. Ten sposób postępowania i myślenia charakteryzował także mieszkańców Sewilli i obszarów Kastylii, pozostających w ścisłych związkach handlowych z Portugalią. W tekstach nie ma natomiast bezpośrednich wzmianek o odwrotnych skutkach kontaktu - to znaczy o przemianie kultury portugalskiej. Prawdopodobnie do początku XVI w. większość Portugalczyków o tym nie myślała i zjawiska tego nie dostrzegała. Było ono znacznie słabsze niż asymilacja i akulturacja czarnych Afrykanów. Wynikało to z miejsca kontaktu - w Europie - oraz z większej zamożności i z atrakcyjności cywilizacji chrześcijańskiej, oczywistej dla Portugalczyków.

Życie w jednym państwie ze stosunkowo liczną grupą Afrykanów, skupionych głównie w miastach, było dla Portugalczyków praktyką dnia codziennego. Wiedziano o tych ludziach wiele. Powszechnie używano informacji o miejscu w Afryce, z którego pochodził niewolnik. Ludzie potrafili rozróżnić czarnych Afrykanów wedle miejsca pochodzenia. Pomimo

${ }^{109}$ V. Fernandes, Description de la Côte d'Afrique de Ceuta au Sénégal (1506-1507), wyd. P. de Cenival, T. Monod, Paris 1938, s. 122: „Exempro, conheçi huum Azenegue que foy tornado em pequeno e criado e christão em Portugal 24 annos, e fugio e foy ter a sua terra e viue assi desnudo e desauenturado pobre e muyto mais que os outros, porque non sabe trabalhar e viue de esmolla dos outros onde bem podera viuer melhor e ter booms vestidos, porem a naturaleza ho non leixou" (tłum. M. Tymowskiego). 
chrztu w niektórych przypadkach przetrwały imiona afrykańskie. Kontakty seksualne, dobrowolne lub wymuszone, przyniosły pojawienie się grupy mulatów. Język Afrykanów był uproszczoną odmianą języka portugalskiego.Jego używanie budziło śmiech i kpiny, co znalazło odzwierciedlenie w literaturze. Było też, poza kolorem skóry i niewolą, elementem stygmatyzującym człowieka, wyznaczającym mu niską pozycję w społeczeństwie. Natomiast chrześcijaństwo integrowało czarnych niewolników ze społeczeństwem.

\section{Cultural-Psychological Aspects of the Presence of African Slaves in Portugal during the Fifteenth Century and the Early Sixteenth Century}

The author analyses the psychological aspects of the slave trade, the presence of slaves in Portugal and the phenomenon of cultural contact between the slaves and the Portuguese. The accepted chronological caesurae span from 1441, i.e. the date of the import of the first slaves, and the beginning of the sixteenth century. The justification of the second caesura are transformations of the intensity and type of slavery transpiring under the impact of the colonisation of the island of St. Thomas and of the trans-Atlantic trade and the development of a plantation economy based on slavery. Slavery in the fifteenth century and the early sixteenth century possessed a separate character both from the viewpoint of the scale of the phenomenon and cultural contact, the theme of the author's research. The programme of the conduct of the Portuguese in relation to African slaves was presented by the chronicler Gomes Eanes Zurara. It consisted to a great extent on a striving towards the Christianisation and acculturation of the slaves. These changes to a large degree succeeded. Christianity integrated the slaves and society, although crossing the barrier of a low social position was impossible, and in the case of the freedmen extremely difficult. At the same time, the presence of African slaves in Portugal exerted an impact upon Portuguese culture. There took place a dissemination of knowledge about Africa and familiarity with African geographical and political names defining the origin of the slaves. There also emerged a separate form of language known as fala dos pretos. The mutual and bilateral impact of Portuguese and African cultures is indubitable but the intensity of such impacts differed. It was defined by the distribution and number of the African slaves, concentrated predominantly in towns, where they comprised a minority totalling several percent of the population. The acculturation of the slaves was the outcome of activities intentionally undertaken, but the influence of African culture upon its Portuguese counterpart was spontaneous and unplanned and its awareness appeared only after their accomplishment.

Translated by Aleksandra Rodzińska-Chojnowska 